Article

\title{
Techno-Economic Comparison of Onshore and Offshore Underground Coal Gasification End-Product Competitiveness
}

\author{
Natalie Nakaten ${ }^{1, *}\left(\mathbb{D}\right.$ and Thomas Kempka ${ }^{1,2}$ \\ 1 GFZ German Research Centre for Geosciences, Fluid Systems Modelling, Telegrafenberg, \\ 14473 Potsdam, Germany \\ 2 University of Potsdam, Institute of Geosciences, Karl-Liebknecht-Str. 24-25, 14476 Potsdam, Germany \\ * Correspondence: natalie.christine.nakaten@gfz-potsdam.de; Tel.: +49-331-288-28722
}

Received: 29 May 2019; Accepted: 28 June 2019; Published: 23 August 2019

\begin{abstract}
Underground coal gasification (UCG) enables utilization of coal reserves, currently not economically exploitable due to complex geological boundary conditions. Hereby, UCG produces a high-calorific synthesis gas that can be used for generation of electricity, fuels, and chemical feedstock. The present study aims to identify economically-competitive, site-specific end-use options for onshore- and offshore-produced UCG synthesis gas, taking into account the capture and storage (CCS) and/or utilization (CCU) of produced $\mathrm{CO}_{2}$. Modeling results show that boundary conditions favoring electricity, methanol, and ammonia production expose low costs for air separation, low compression power requirements, and appropriate shares of $\mathrm{H}_{2} / \mathrm{N}_{2}$. Hereby, a gasification agent ratio of more than $30 \%$ oxygen by volume is not favorable from the economic and $\mathrm{CO}_{2}$ mitigation viewpoints. Compared to the costs of an offshore platform with its technical equipment, offshore drilling costs are marginal. Thus, uncertainties related to parameters influenced by drilling costs are negligible. In summary, techno-economic process modeling results reveal that air-blown gasification scenarios are the most cost-effective ones, while offshore UCG-CCS/CCU scenarios are up to 1.7 times more expensive than the related onshore processes. Hereby, all investigated onshore scenarios except from ammonia production under the assumed worst-case conditions are competitive on the European market.
\end{abstract}

Keywords: underground coal gasification (UCG); economics; cost of electricity (COE); techno-economic model; methanol; ammonia; carbon capture and storage (CCS); carbon capture and utilization (CCU); electricity generation; process simulation

\section{Introduction}

Underground coal gasification (UCG) can provide an economic approach to increase worldwide coal reserves by utilization of coal deposits that are currently not mineable by conventional methods. Hereby, the target coal seam is converted into a synthesis gas within a controlled, sub-stoichiometric gasification process [1-5]. After processing, UCG synthesis gas is applicable for different end-uses as, e.g., provision of chemical raw materials, liquid fuels, hydrogen, fertilizers, or electricity (cf. Figure 1). The early idea of UCG and its evolution has a long history that was picked up especially at times of hydrocarbon scarcity. Since the 1930s, more than 50 pilot-scale UCG operations have been carried out worldwide, e.g., in the former Union of Soviet Socialist Republics (USSR), Europe, the U.S., South Africa, Australia, and China. Predominantly, these tests have been undertaken at shallow depths, e.g., at Angren (110 m) in Uzbekistan, Chinchilla (140 m) in Australia, and Hanna (80 m) and Hoe Creek (30-40 m) in the U.S [1-4,6]. One recent pilot-scale UCG installation in Poland was 
constructed in 2010 at about a $400 \mathrm{~m}$ depth in order to gasify 1,300 metric tons of coal at an average rate of $600 \mathrm{~kg} / \mathrm{h} \mathrm{[7-10].}$

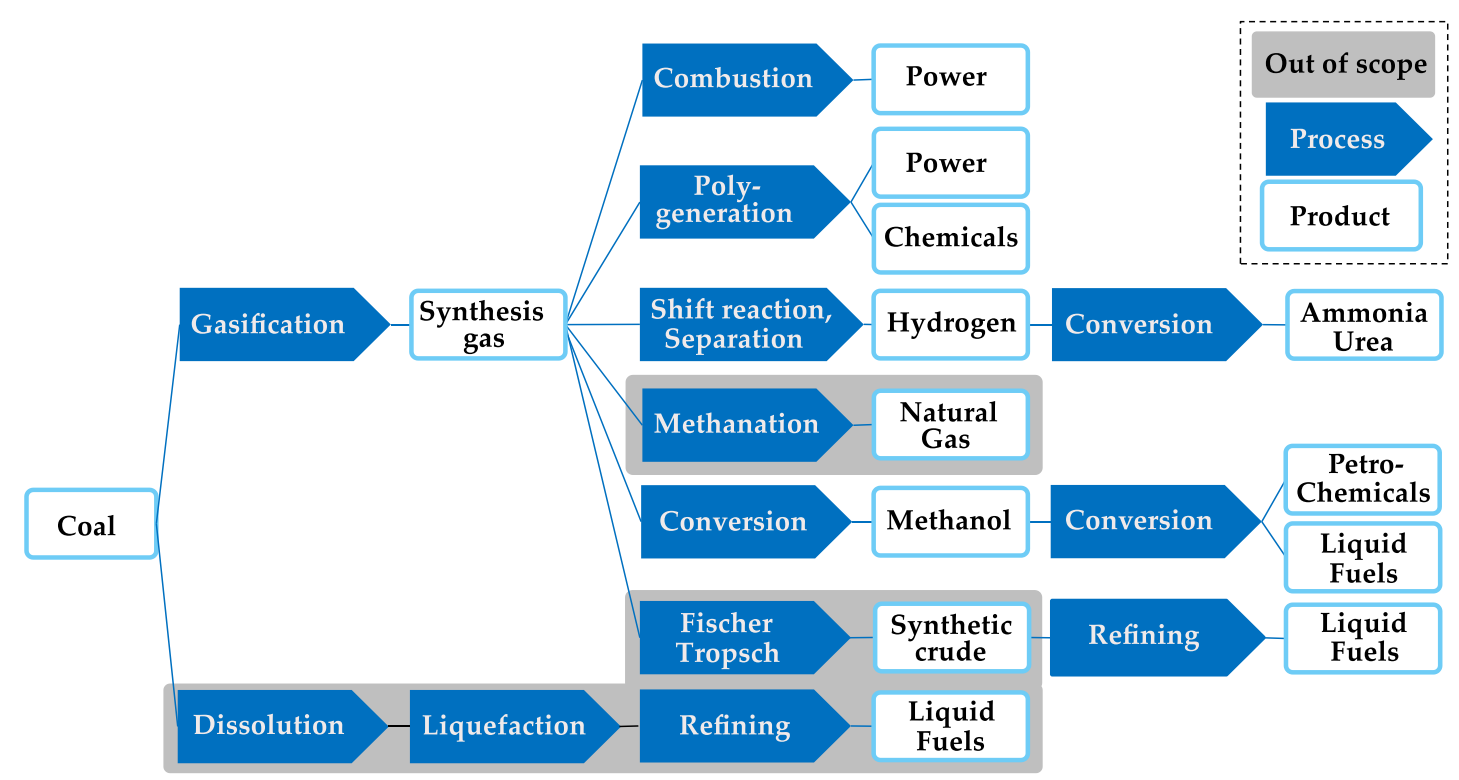

Figure 1. Supply chains for different underground coal gasification end-use options analyzed in the present study (electricity generation, hydrogen production, and its utilization for methanol and ammonia synthesis), modified from Kinaev et al. [11].

The in-situ UCG trial at the Wieczorek mine (cf. Figure 2) was part of the Polish research project "Elaboration of coal gasification technologies for a high efficiency production of fuels and electricity" [12]. The results of the pilot-scale research at the Wieczorek mine serve as the basis for the development of prospective commercial-scale UCG operations in the Upper Silesian Basin.

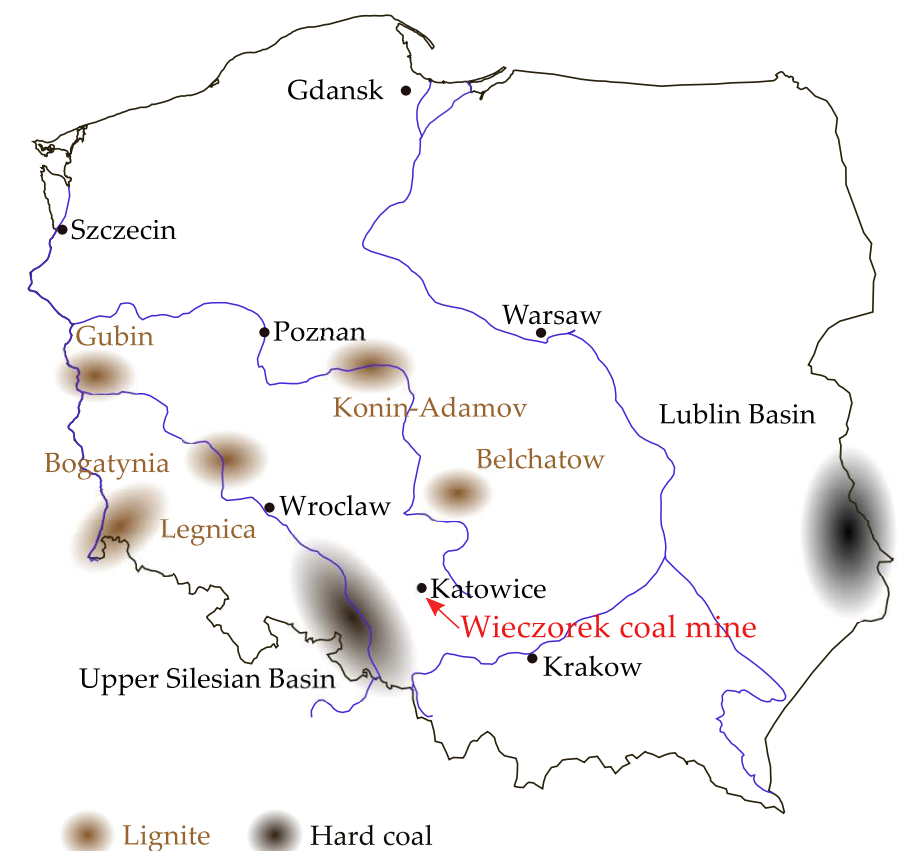

Figure 2. Location of the selected study area (Wiezcorek coal mine) in Poland. Modified from the European Association for Coal and Lignite (EURACOAL) [13]. 
In view of the underlying techno-economic study, the wide data basis available from the Polish UCG pilot test, as well as representative coal samples offer a solid basis to parametrize the techno-economic process and life cycle assessment models [14,15]. Hence, the present study aims at a transparent documentation of the techno-economic analysis to identify economically-competitive site-specific UCG synthesis gas based end-utilization options. In order to handle carbon emissions resulting from the combustion of coal, the UCG process is linked to the capture and subsequent storage of $\mathrm{CO}_{2}$ (CCS) in saline aquifers and/or its utilization (CCU) as a raw material for fuel production. Taking into account the comprehensive domestic coal resources, the EU environmental guidelines claiming a reduction of import dependency, a reduction of $\mathrm{CO}_{2}$ emissions, and an increase in energy efficiency [16], integrated UCG-CCS/CCU processes may offer approaches to meet all of these criteria for Poland.

The tool applied for economic assessment is the techno-economic model developed by Nakaten et al. [5]. This model is applicable to calculate the costs of using UCG synthesis gas for electricity generation in a combined cycle gas turbine (CCGT) power plant coupled with CCS, taking into account site-specific geological, chemical, technical, and market-dependent boundary conditions. It consists of six sub-models (cf. Figure 3) and is controlled by more than 130 model input parameters, adaptable to site-specific boundary conditions for any study area. For the present study, the techno-economic model was extended to include UCG-based methanol and ammonia production (cf. Figure 3), as well as a corresponding offshore UCG setup (cf. Section 2.2.2).

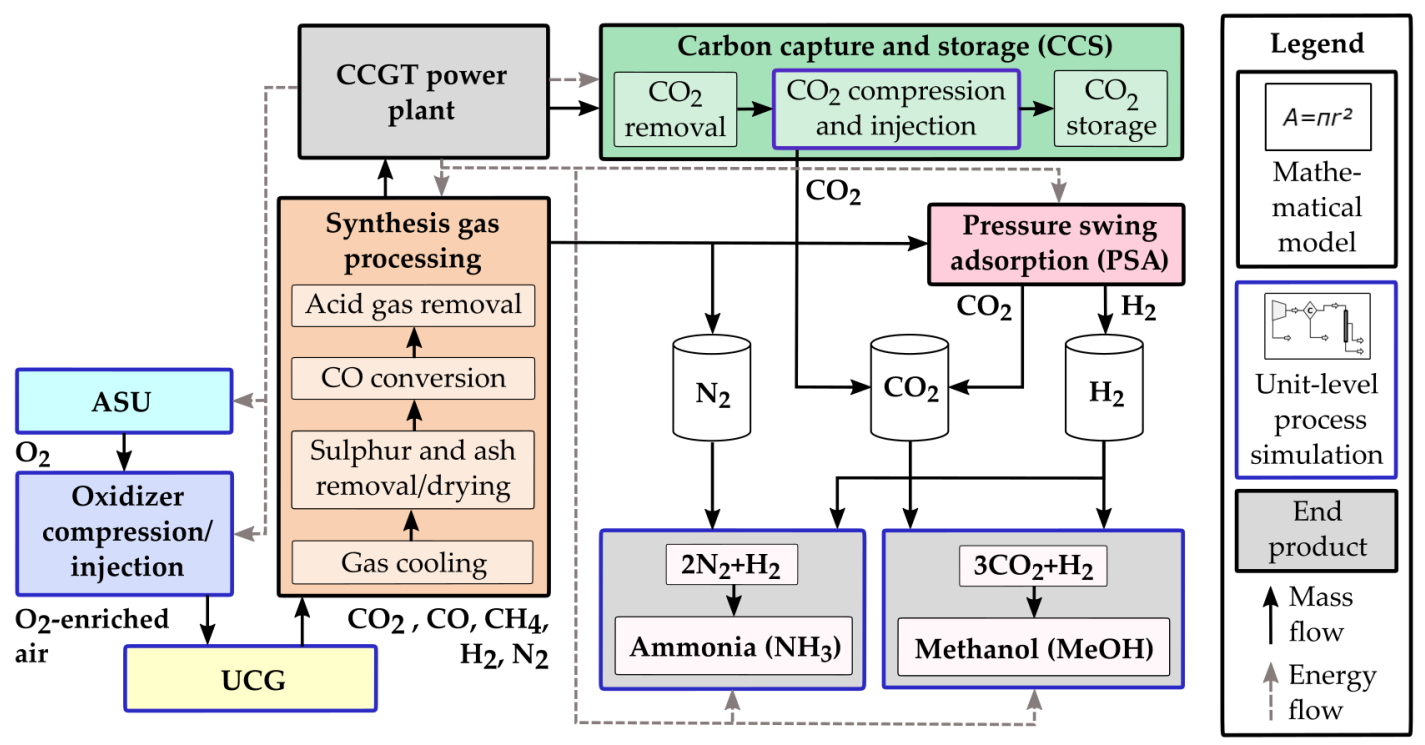

Figure 3. Techno-economic model for cost determination of integrated underground coal gasification (UCG), carbon capture and storage (CCS)/ carbon capture, and utilization (CCU) scenarios based on Nakaten et al. [5] and extended to fulfill the requirements of the present study.

Innovations provided within the present study are:

- The implementation of a mass and energy balance assessment related to air separation (ASU), $\mathrm{CO}_{2}$ compression, $\mathrm{CO}_{2}$ and gasification agent injection, UCG synthesis gas production, and methanol and ammonia synthesis (cf. Figure 3, blue bordered boxes) to identify process steps requiring energy-saving measures, and

- the assessment of individual synthesis gas composition components and the related applied gasification agent, impacting overall levelized onshore and offshore costs.

Results obtained from quantification of cost bandwidths by single model parameter variation and comparing offshore to onshore levelized costs for selected UCG-CCS/CCU scenarios show that offshore UCG-based methanol and ammonia production are up to 1.7 times more expensive than the related 
onshore processes. Nevertheless, considering the average market prices in 2018, offshore methanol production is yet competitive on the European market, whereby the offshore ammonia production scenario costs exceed the current ammonia market price by $34 \%$. With regard to the onshore scenarios, all investigated UCG-CCS/CCU processes except for ammonia production at the assumed worst-case conditions are economically competitive. Furthermore, techno-economic modeling results revealed that compared to the offshore platform with its technical equipment, offshore drilling costs have a minor impact of up to $3 \%$ on total levelized costs, only. Hence, uncertainties related to parameters influenced by drilling costs are negligible. Besides, results point out approaches for a cost-effective commercial-scale UCG-CCS/CCU implementation. The most important aspect required to maintain low production costs is a precise management of the gasification agent composition, whereby an oxygen ratio of a maximum of $30 \%$ by volume is suggested to maintain low ASU costs. Besides, methanol and ammonia production also significantly benefit from high $\mathrm{H}_{2} / \mathrm{N}_{2}$ and low $\mathrm{CO}_{2}$ amounts. In the present study, the synthesis gas composition with the lowest $\mathrm{CO}_{2}$ share sums up to $6.43 \%$ (reference scenario). Here, $26 \% \mathrm{CO}_{2}$ are sufficient to supply methanol synthesis at a yield of about $490 \mathrm{kt} /$ year, determined constantly as output for all investigated methanol production scenarios.

\section{Materials and Methods}

Within the underlying section, basic model assumptions, the calculation methods applied, and intermediate calculation results, fundamental for the involved onshore and offshore UCG-CCS/CCU scenarios, are discussed.

\subsection{Dimensioning of Assessed UCG-Based Production Chains}

Selected onshore UCG synthesis gas end-use options in line with the present study are electricity generation, as well as methanol and ammonia production. Hereby, the dimensions of involved facilities were adapted to representative commercial-scale plant capacities. For electricity generation, an installed plant capacity of $100 \mathrm{MW}$ net generation was chosen. Gross generation amounts were up to $286 \mathrm{MW}$, ensuring energy supply for air separation, gas processing, and compression. Following the model setup presented by Perez et al. [17], methanol production amounts were up to about $490 \mathrm{kt}$ per year. The amount of produced ammonia was determined as $314 \mathrm{kt}$ per year, representing an average Polish ammonia plant capacity [18]. Hereby, the product outputs listed above were maintained constant for all investigated scenarios to allow for their comparability.

\subsection{Applied UCG Technologies and Well Design}

\subsubsection{Onshore UCG Technology Implementation}

For the target coal seam utilization, we considered the Controlled Retraction Injection Point (CRIP) technology [1-3]. Key data related to geological boundary conditions (cf. Table 1) and coal seam extraction (cf. Table 2) were adapted from the coupled thermo-mechanical 3D UCG model setup introduced by Otto et al. [19], as well as data elaborated by Otto et al. [20,21].

Table 1. Geological data of the target coal seam, adapted from Otto et al. [19].

\begin{tabular}{lc}
\hline Model Input Parameters & Value \\
\hline Average coal seam thickness $(\mathrm{m})$ & 11.0 \\
Average coal calorific value $(\mathrm{MJ} / \mathrm{kg})$ & 29.0 \\
Average dip angle of the coal seam $\left(^{\circ}\right)$ & 8.6 \\
Average coal seam depth $(\mathrm{m})$ & 475.0 \\
Average coal density $\left(\mathrm{t} / \mathrm{m}^{3}\right)$ & 1.281 \\
\hline
\end{tabular}

The suggested optimized vertical well layout for injection and production, as well as the network of lined deviated injection boreholes, drilled horizontally into the coal seam, are presented in Figure 4. 
To achieve an individual control of the UCG process by managing gasification agent injection rates and liner retraction, each gasification channel is operated by a separate liner, introduced by a separate injection well.

Aiming at an energy-efficient injection process, we iteratively determined inner liner well diameters, using thermodynamic process simulations integrated into the techno-economic model [22] to maintain effective flow velocities and related pressure losses. For thermodynamic modeling, we applied the DWSIM software package [22] with the ChemSepdatabase [23], whereby interfaces between techno-economic and thermodynamic models were established via a DWSIM control module (cf. Figure 5).

Allowing for pressure losses of a max. of 2 bar, inner-well diameters for injection and production wells were aligned according to a gasification agent mass flow of up to $13.7 \mathrm{~kg} / \mathrm{s}$ per injection well, a synthesis gas mass flow of up to $18.5 \mathrm{~kg} / \mathrm{s}$ per production well, and a $\mathrm{CO}_{2}$ mass flow of up to $28.3 \mathrm{~kg} / \mathrm{s}$ per $\mathrm{CO}_{2}$ injection well. Adhering to the chosen inner-well diameters of 7 inches for gasification agent injection, 9 inches for all production, and $\mathrm{CO}_{2}$ injection wells, as well as significantly differing mass flow rates in the three model setups (cf. Table 2), the number of required simultaneously-operated injection and production wells varied significantly (cf. Table 2). However, we neglected to develop separate well layouts that would hardly differ from an economical point of view. Hereby, smaller inner-liner diameters allowed for higher achievable build-up rates, and thus less drilling meters. Further simulation constraints that influence the density and viscosity of the gas mixtures, and thus pressure losses in wells, were determined by the hydraulic and thermal well profiles, as well as temperature and pressure conditions at the well heads or at the production well bottomhole. The hydraulic well profile comprises information on the well casing material, length and diameter.

Based on the inner liner diameters of the injection wells, the achievable build-up rates of the deviated drillings were determined as $6^{\circ}$ per $30.48 \mathrm{~m}$ (100 ft) according to Godbolt [24]. Referring to thermomechanical modeling results on channel stability in the absence of subseismic faults, a pillar width of $60 \mathrm{~m}$ (cf. Figure 4) is sufficient to avoid inter-channel hydraulic short circuits [19]. The achievable gasification channel width in the Wieczorek target coal seam amounts to $20 \mathrm{~m}$ (cf. Table 2) according to Otto et al. [19]. In order to ensure the required synthesis gas feed in the reference scenario for an overall operational lifetime of 20 years, the operation of 1.2 UCG panels (15 gasification channels) is required for electricity generation. For methanol and ammonia production, up to four UCG panels are required (cf. Table 2) to ensure energy supply for a 20-year operational lifetime.

Table 2. UCG design for a $2 \mathrm{~km} \times 1 \mathrm{~km}$-sized target area adapted from Otto et al. [19] and adjusted to the electricity, methanol, and ammonia production scenarios.

\begin{tabular}{lcccc}
\hline Key Data & Electricity & Methanol & Ammonia & Reference \\
\hline UCG panel width $(\mathrm{km})$ & 1.9 & 1.9 & 1.9 & {$[19-21]$} \\
UCG panel length $(\mathrm{km})$ & 1.0 & 1.0 & 1.0 & {$[19-21]$} \\
UCG panel coal resources (Mt) & 7.3 & 7.3 & 7.3 & Calculated \\
Channel width-to-height ratio (-) & 1.8 & 1.8 & 1.8 & {$[19-21]$} \\
Number of simultaneously-operated production wells (-) & 4.0 & 13.0 & 8.0 & Calculated \\
Number of injection wells per UCG panel (-) & 13.0 & 13.0 & 13.0 & Calculated \\
Number of simultaneously-operated injection wells (-) & 4.0 & 13.0 & 8.0 & Calculated \\
Gasification channel width (m) & 20.0 & 20.0 & 20.0 & {$[19-21]$} \\
Distance between gasification channels (m) & 60.0 & 60.0 & 60.0 & {$[19-21]$} \\
Total coal consumption (Mt) & 8.5 & 26.5 & 16.4 & Calculated \\
Total required gasification agent mass (Mt) & 34.3 & 110.0 & 68.8 & Calculated \\
UCG panels required (-) & 1.2 & 3.6 & 2.2 & Calculated \\
\hline
\end{tabular}




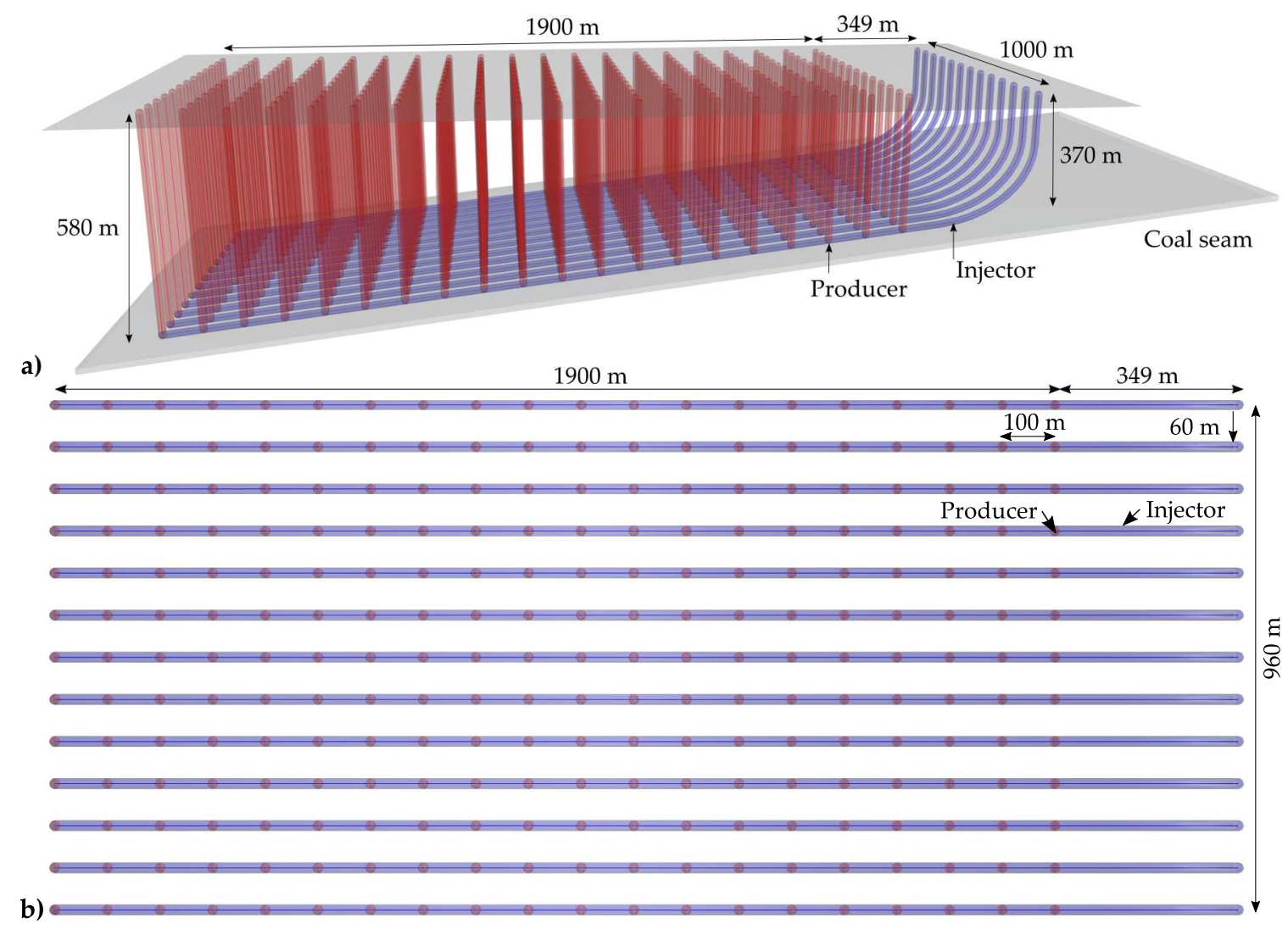

Figure 4. Computer-aided design model visualizing (a) 3D perspective and (b) plan views of the conceptual technical onshore well design for one underground coal gasification panel with 13 reactor channels and 260 production wells.

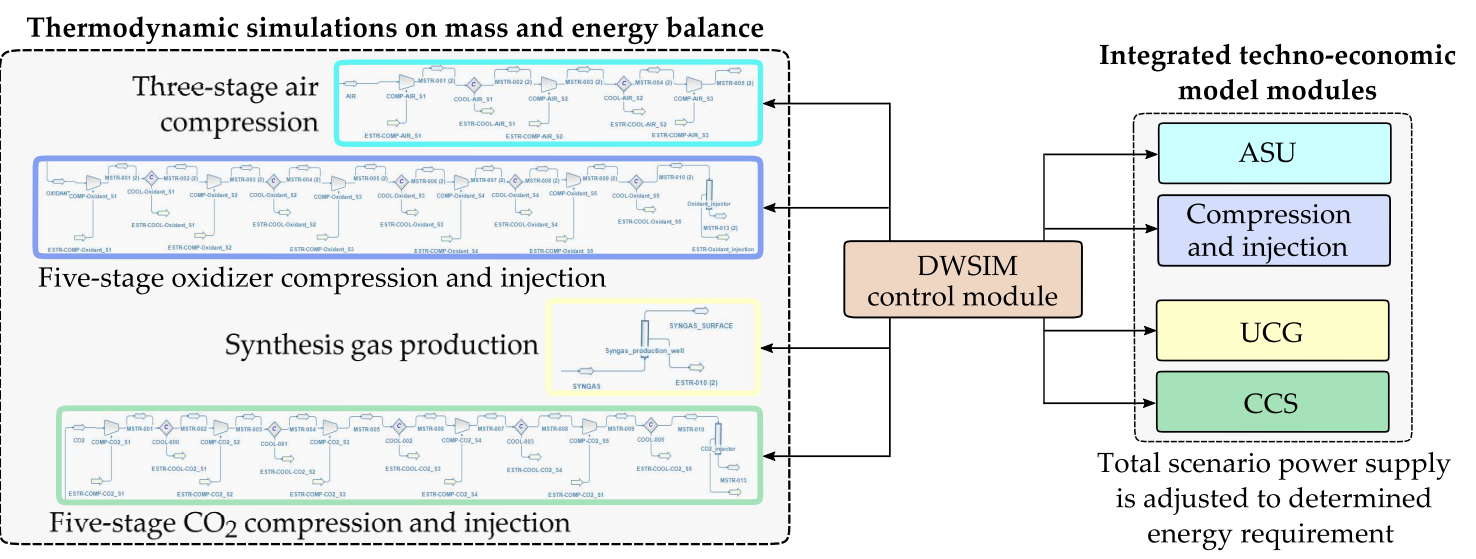

Figure 5. Integration of the techno-economic model with thermodynamic process simulations by means of the DWSIM process simulator [22], considering air compression, oxidizer compression and injection, synthesis gas production, as well as $\mathrm{CO}_{2}$ compression and injection.

Production wells are drilled vertically from the surface and spaced at a distance of $100 \mathrm{~m}$ along the horizontal extension of each gasification channel (cf. Figure 4). This distance is considered appropriate to avoid consumption of high-value product gas components (synthesis gas cannibalism) along the gasification channels $[1,4,25]$. In line with the extraction of a complete UCG panel at a width of $2 \mathrm{~km}, 260$ production wells are required. Taking into account the number of simultaneously-operated gasification channels (cf. Table 2), the total coal consumption, as well as geometrical gasification channel data (cf. Tables 1 and 2), an average daily horizontal gasification front progress of up to one meter can 
be achieved $[19,26]$. The overall coal yield using the chosen UCG well layout was about $25 \%$. Drilling costs (cf. Table 3) were calculated based on the total number of required injection and production wells, as well as the target coal seam dimensions (cf. Tables 1 and 2). Within the UCG sub-model (cf. Figure 3), all cost positions associated with gasification agent production, its compression and injection (Section 2.3), synthesis gas processing (Section 2.4), drilling, land acquisition, piping, measuring, control equipment costs, as well as land concession fees and permissions were combined. Table 4 lists all synthesis gas production costs for electricity, methanol, and ammonia production.

Table 3. Calculated drilling meters and resulting costs for injection and production wells for the onshore electricity, methanol, and ammonia production scenarios.

\begin{tabular}{lcccc}
\hline Cost Position & Electricity & Methanol & Ammonia & Reference \\
\hline Vertical drilling length $(\mathrm{km})$ & 188.50 & 590.80 & 364.50 & CAD model \\
Deviated drilling length $(\mathrm{km})$ & 0.60 & 1.90 & 1.20 & CAD model \\
Horizontal drilling length $(\mathrm{km})$ & 30.30 & 95.10 & 58.70 & CAD model \\
\hline Costs vertical drilling meter $(€ / \mathrm{m})$ & 80.00 & 80.00 & 80.00 & {$[12,14,27,28]$} \\
Costs deviated drilling meter $(€ / \mathrm{m})$ & 480.00 & 480.00 & 480.00 & {$[12,14,27,28]$} \\
Costs horizontal drilling meter $(€ / \mathrm{m})$ & 230.00 & 230.00 & 230.00 & {$[12,14,27,28]$} \\
\hline Cumulative costs vertical drilling $(\mathrm{M} €)$ & 15.08 & 47.26 & 29.16 & Calculated \\
Cumulative costs deviated drilling $(\mathrm{M} €)$ & 0.30 & 0.93 & 0.57 & Calculated \\
Cumulative costs horizontal drilling $(\mathrm{M} €)$ & 6.98 & 21.87 & 13.49 & Calculated \\
\hline Total drilling costs $(\mathbf{M} €)$ & $\mathbf{2 2 . 3 6}$ & $\mathbf{7 0 . 0 6}$ & $\mathbf{4 3 . 2 2}$ & Calculated \\
\hline
\end{tabular}

Table 4. Total onshore UCG costs for a 20-year operation of onshore electricity, methanol, and ammonia production scenarios.

\begin{tabular}{lcccc}
\hline Cost Position & Electricity & Methanol & Ammonia & Reference \\
\hline Fees for area, permission, exploration $(\mathrm{M} €)$ & 1.96 & 2.48 & 2.22 & {$[12,14,27,28]$} \\
Total drilling costs $(\mathrm{M} €)$ & 22.36 & 70.05 & 43.22 & Calculated \\
Land acquisition costs $(\mathrm{M} €)$ & 59.29 & 118.58 & 88.93 & {$[12,14,27,28]$} \\
Piping, measuring, control equipment costs $(\mathrm{M} €)$ & 14.20 & 60.71 & 28.52 & {$[29]$} \\
Gasification agent production/injection costs $(\mathrm{M} €)$ & 350.55 & 725.55 & 514.94 & {$[30]$} \\
Synthesis gas processing costs $(\mathrm{M} €)$ & 279.96 & 261.33 & 248.30 & {$[29]$} \\
Pressure swing adsorption (PSA) costs $(\mathrm{M} €)$ & - & 374.20 & 234.38 & {$[31]$} \\
Staff salaries $(\mathrm{M} €)$ & 104.37 & 129.44 & 81.08 & {$[29]$} \\
\hline Total costs $(\mathbf{M} €)$ & $\mathbf{8 3 2 . 6 9}$ & $\mathbf{1 7 4 2 . 3 4}$ & $\mathbf{1 2 4 1 . 5 9}$ & Calculated \\
\hline
\end{tabular}

\subsubsection{Offshore UCG Technology Implementation}

We applied a modified version of the model developed by Nakaten et al. [5] to assess the costs of two offshore UCG-CCS/CCU production chains aiming at methanol and ammonia generation. For comparability, the generic offshore model parametrization was equal to that of the previously-discussed onshore model. Revised model assumptions were primarily varying due to the adapted UCG well design and increased costs accounted for the offshore infrastructure. Furthermore, we did not consider a power generation scenario for the offshore UCG-CCS/CCU economic assessment in favor of methanol and ammonia production. Electricity production exceeding the offshore UCG platform's own demand was of limited applicability, since installation of costly offshore transport networks would be required. This is not considered to be as economic as, e.g., the transport of methanol or ammonia by ships. While varying methanol and/or ammonia production capacities do not significantly impact the overall production costs, electricity generation economics strongly depend on a continuous power supply to an electricity network $[32,33]$.

Figure 6 shows the suggested radial development design for offshore coal seam extraction, taking into account the parallel controlled retracting injection point (P-CRIP) UCG approach [34-37]. 
To maximize the coal extraction in one offshore panel using 25 gasification channels, injection and production wells were drilled in-seam next to each other [37]. Applying this well layout, a maximum coal yield of $46 \%$ can be achieved. Hereto, we implemented alternating "long" (about $1000 \mathrm{~m}$ ) and "short" (650 m) gasification channel systems to optimize the coal yield (cf. Figure 6), considering a safety distance (pillar width) of at least $100 \mathrm{~m}$ between the single gasification channels. We validated the chosen safety distance in view of potential hydraulic short circuit formation between single UCG reactors and seabed level subsidence by numerical geomechanical simulations [37].

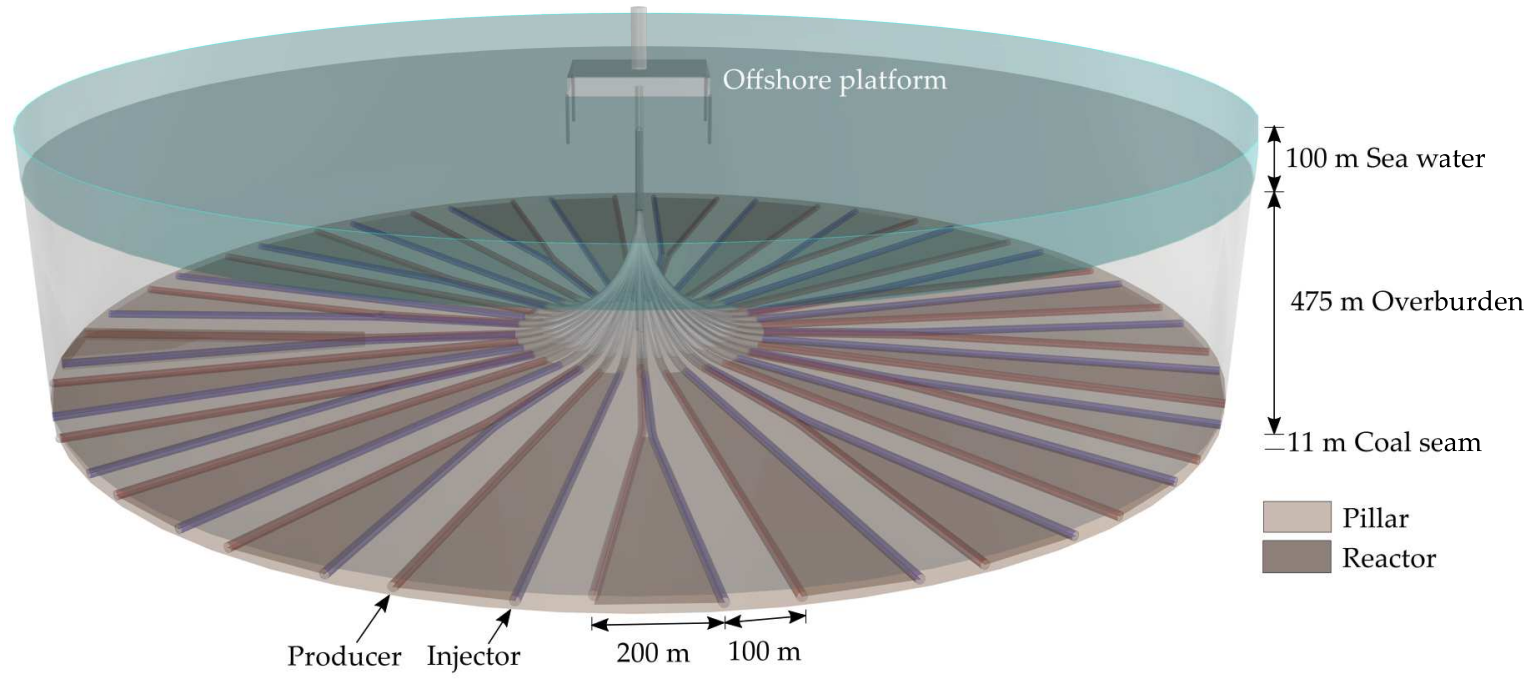

Figure 6. Computer-aided design model visualizing the proposed parallel controlled retracting injection point underground coal gasification offshore well design with twelve "long" and 13 "short" channel systems. Figure copyright [36] (modified), licensed under CC BY-NC-ND 4.0.

For the reference scenario, we assumed a maximum gasification channel width of $200 \mathrm{~m}$, decreasing to $45 \mathrm{~m}$ ("long" channel system) and about $20 \mathrm{~m}$ ("short" channel systems) at the narrow parts close to the circle center. We further implemented different scenarios with maximum gasification channel widths from 50-200 m and quantified the resulting cost bandwidth (cf. Section 3.4.3) to consider economic uncertainties resulting from the assumed maximum achievable gasification channel width. The proposed well design allowed for the extraction of about $34 \mathrm{Mt}$ coal per panel. Thus, taking into account an average daily coal consumption rate of $3.6 \mathrm{kt}$ for methanol and $2.2 \mathrm{kt}$ for ammonia production in the reference scenario, one coal panel was sufficient to ensure the operation for 20 years. Data on the geological boundary conditions of the offshore UCG design are listed in Table 5.

Table 5. Boundary conditions for the radial offshore UCG well design in the reference scenario [37].

\begin{tabular}{lc}
\hline Model Input Parameters & Value \\
\hline Average coal seam thickness $(\mathrm{m})$ & 11.0 \\
UCG panel radius $(\mathrm{km})$ & 1.3 \\
Overall UCG panel extension $\left(\mathrm{km}^{2}\right)$ & 5.3 \\
Extractable coal resources per UCG panel $(\mathrm{Mt})$ & 33.8 \\
Pillar width $(\mathrm{m})$ & 100.0 \\
\hline
\end{tabular}

Due to the lack of data, offshore drilling costs were determined based on the previously-introduced onshore drilling costs (cf. Table 3). Since offshore drilling (cf. Table 6) is significantly more expensive than onshore drilling, we conservatively assumed five times higher drilling costs in the offshore reference scenario (cf. Table 7). Uncertainties related to offshore drilling costs were further assessed and quantified in the scope of the sensitivity analysis. Total UCG costs for offshore methanol production summed up to $2.9 \mathrm{G} €$ and to $2.4 \mathrm{G} €$ for offshore ammonia production. 
Table 6. Drilling meters in the offshore methanol and ammonia production scenarios.

\begin{tabular}{lcc}
\hline Drilling Meters (m) & Methanol & Ammonia \\
\hline Deviated & 15,521 & 9,130 \\
Horizontal & 34,006 & 19,989 \\
Vertical & 6,180 & 3,635 \\
\hline Total drilling meters (m) & $\mathbf{5 5 , 7 0 7}$ & $\mathbf{3 2 , 7 5 4}$ \\
\hline
\end{tabular}

Table 7. Drilling costs in the offshore methanol and ammonia production scenarios.

\begin{tabular}{lcc}
\hline Cost Position & Methanol & Ammonia \\
\hline Cumulated costs for deviated drilling meters $(\mathrm{M} €)$ & 37.3 & 21.9 \\
Cumulated costs for horizontal drilling meters $(\mathrm{M} €)$ & 39.1 & 23.0 \\
Cumulated costs for vertical drilling meters $(\mathrm{M} €)$ & 2.5 & 1.5 \\
\hline Total drilling costs $(\mathrm{M} €)$ & $\mathbf{7 8 . 9}$ & 46.4 \\
\hline
\end{tabular}

\subsection{Costs for UCG Offshore Platform}

According to Boeing [38], we considered CAPEX of about $620 \mathrm{M} €$ for the construction of an offshore platform (corrected for inflation) and further $620 \mathrm{M} €$ for technical services and material costs for 20 years of operation. As for the onshore scenarios, transportation was not considered in the UCG offshore cost determination.

\subsection{Gasification Agent Compression and Injection}

For comparability, process dimensions of the offshore and onshore models were equalized, thus parametrization related to gasification agent production, compression, and injection, as well as the related intermediate results were comparable. To provide a gasification agent mixture consisting of $30 \% \mathrm{O}_{2}$ and $70 \% \mathrm{~N}_{2}$ by volume, a cryogenic air separation unit (ASU) was considered. Air compression in the ASU process was implemented within three stages, whereby modeling results on the total power requirement, obtained from thermodynamic process simulations using the DWSIM software package [22], summed up to about $16 \mathrm{MW}$ for onshore electricity generation. Air compression power demand of methanol production amounted to $51 \mathrm{MW}$ and $32 \mathrm{MW}$ for ammonia production. Gasification agent compression before its injection was achieved within five stages, resulting in a total compression power requirement of $28 \mathrm{MW}$ (electricity), $88 \mathrm{MW}$ (methanol), and $55 \mathrm{MW}$ (ammonia), respectively. Total CAPEX and OPEX for the ASU process, as well cost positions related to gasification agent compression and injection in the onshore and offshore reference scenarios are listed in Table 8.

Electricity costs were neglected, since the power requirement for all process stages is autonomously provided by the integrated CCGT power plant (onshore) or a gas turbine at the offshore platform. 
Table 8. Air separation costs in the onshore/offshore reference scenarios with an air feed demand of $70 \mathrm{~kg} / \mathrm{s}$ for onshore electricity production, as well as 222 and $139 \mathrm{~kg} / \mathrm{s}$ for onshore/offshore methanol and ammonia production for 20 years of operation, modeled with IECM [30].

\begin{tabular}{|c|c|c|c|}
\hline CAPEX & Electricity & $\mathrm{MeOH}$ & $\mathbf{N H}_{3}$ \\
\hline Process facilities capital $(\mathrm{M} €)$ & 64.2 & 101.5 & 77.8 \\
\hline General facilities capital (M€) & 9.6 & 15.2 & 11.7 \\
\hline Staff costs $(\mathrm{M} €)$ & 6.4 & 10.2 & 7.8 \\
\hline Project and process contingency costs $(\mathrm{M} €)$ & 12.8 & 20.3 & 15.6 \\
\hline Interest charges $(\mathrm{M} €)$ & 5.0 & 7.9 & 6.1 \\
\hline Royalty fees $(\mathrm{M} €)$ & 0.3 & 0.5 & 0.4 \\
\hline Pre-production (start-up) costs $(\mathrm{M} €)$ & 2.3 & 3.6 & 2.8 \\
\hline Inventory (working) capital $(\mathrm{M} €)$ & 0.5 & 0.7 & 0.6 \\
\hline Total ASU CAPEX (M€) & 101.1 & 159.9 & 122.8 \\
\hline OPEX (variable and fixed costs) & Electricity & $\mathrm{MeOH}$ & $\mathrm{NH}_{3}$ \\
\hline Variable costs $(\mathrm{M} €)$ & 52.6 & 168.6 & 105.6 \\
\hline Operating labor $(\mathrm{M} €)$ & 31.0 & 49.1 & 37.6 \\
\hline Maintenance labor $(\mathrm{M} €)$ & 14.9 & 23.5 & 18.1 \\
\hline Maintenance material $(\mathrm{M} €)$ & 22.3 & 35.3 & 27.1 \\
\hline Admin and support labor $(\mathrm{M} €)$ & 15.9 & 25.2 & 19.3 \\
\hline Total ASU OPEX (M€) & 136.7 & 301.7 & 207.7 \\
\hline Total ASU CAPEX and OPEX (M€) & 237.8 & 461.6 & 330.5 \\
\hline
\end{tabular}

\subsection{Synthesis Gas Processing}

For the techno-economic modeling of the selected UCG end-product utilization options, we considered a synthesis gas composition of $15.90 \% \mathrm{H}_{2}, 1.20 \% \mathrm{CH}_{4}, 6.43 \% \mathrm{CO}_{2}, 17.54 \% \mathrm{CO}$, and $58.93 \% \mathrm{~N}_{2}$ including $0.30 \%$ of minor constituents such as $\mathrm{C}_{2} \mathrm{H}_{2}$ and $\mathrm{H}_{2} \mathrm{~S}$ (all data given in \% by volume). This composition was achieved during the first stage of a five-stage in-situ UCG gasification test at the Wieczorek mine [8], in which different gasification agent compositions at each gasification stage were analyzed. The oxygen fraction in the gasification agent applied in the present study amounted to $25 \%$ by volume. The average synthesis gas calorific value achieved during this stage was $4.4 \mathrm{MJ} / \mathrm{sm}^{3}$. After its transportation to the surface via production wells, the synthesis gas was cooled, scrubbed to remove trace elements, and excess water was separated. Subsequently, the synthesis gas was processed in a gas cleaning section, whereby $\mathrm{CO}$ was converted into $\mathrm{CO}_{2}$ in a $\mathrm{CO}$-shift reactor. Thereafter, sulfur components and $\mathrm{CO}_{2}$ were removed during a physical absorption process. In line with methanol and ammonia production, $\mathrm{CO}_{2}$ and $\mathrm{H}_{2}$ were separated from the synthesis gas by means of physical adsorption (PSA) [39-41], considering a subsequent tail gas disposition block for separation of sulfur-containing compounds.

CAPEX and OPEX for synthesis gas processing (cf. Table 9) using the Selexol process were determined by the Integrated Environmental Control Model (IECM)

modeling tool [30] and scaled linearly to the dimensions of the underlying operational UCG setup by three scaling factors (net output, operating hours, gas flow rate). For electricity generation, synthesis gas processing CAPEX summed up to $132 \mathrm{M} €$ and variable and fixed costs to $7 \mathrm{M} € /$ year. Synthesis gas processing costs for methanol and ammonia production with tail gas cleaning (Beavon-Stretford) summed up to CAPEX of $115.5 \mathrm{M} €$ and 102.5 M€, respectively; as well as OPEX of up to $6.9 \mathrm{M} €$ /year for each of both. Costs for the PSA process (cf. Table 4) were calculated according to Barranon [31], taking into account an interest rate of $10 \%$, as well as an operational lifetime of 20 years. For improved cost comparability, generic model assumptions of the offshore and onshore models were equalized. 
Table 9. Synthesis gas processing costs for a synthesis gas mass flow of $2.3 \mathrm{Mt} /$ year in the electricity production scenario with 20 years of operation, modeled with IECM [30].

\begin{tabular}{lc}
\hline CAPEX & Value \\
\hline Selexol sulfur removal unit $(\mathrm{M} €)$ & 46.2 \\
Process facilities capital $(\mathrm{M} €)$ & 49.4 \\
General facilities capital $(\mathrm{M} €)$ & 7.4 \\
Staff fees (M€) & 4.9 \\
Project and process contingency cost $(\mathrm{M} €)$ & 10.8 \\
Interest charges (M€) & 8.1 \\
Royalty fees (M€) & 0.3 \\
Pre-production (start-up) costs $(\mathrm{M} €)$ & 4.2 \\
Inventory (working) capital $(\mathrm{M} €)$ & 0.7 \\
\hline Total CAPEX (M€) & $\mathbf{1 3 2 . 0}$ \\
\hline OPEX (variable and fixed costs) & Value \\
\hline Selexol solvent $(\mathrm{M} €$ ) & 2.3 \\
Sulfur by-product (M€) & 7.5 \\
Operating labor $(\mathrm{M} €)$ & 81.3 \\
Maintenance labor (M€) & 11.6 \\
Maintenance material (M€) & 17.4 \\
Administrative and support labor $(\mathrm{M} €)$ & 27.9 \\
\hline Total OPEX (M€) & $\mathbf{1 4 8 . 0}$ \\
\hline Total CAPEX and OPEX (M€) & $\mathbf{2 8 0 . 0}$ \\
\hline
\end{tabular}

\section{6. $\mathrm{CO}_{2}$ Capture and Storage and Utilization}

Three existing technologies can be employed to capture $\mathrm{CO}_{2}$ from fossil-fueled power plants: post-combustion, pre-combustion, and oxy-fuel combustion capture $[40,42,43]$. In the present study, we chose a typical physical absorption pre-combustion process by means of a Selexol solvent, suitable for high $\mathrm{CO}_{2}$ capture ratios (95\% considered in our calculations) and common for IGCC power plants [44]. Hereby, the Selexol procedure requires less equipment for dehydration, solvent recovery, and $\mathrm{CO}_{2}$ compression compared to the Rectisol process [41]. Nevertheless, purification of hydrogen and carbon dioxide, crucial for methanol and ammonia syntheses, requires the application of the pressure swing adsorption (PSA) method with a subsequent tail gas disposition block. The PSA procedure is based on a physical binding of gas molecules to adsorbent material. Most of the modern plants used multi-bed PSA to remove water, ethane, and CO for the recovery of high-purity hydrogen $(99.99 \%)$. Carbon dioxide is also separated during this process with a capture ratio of $90 \%[45,46]$.

In view of $\mathrm{CO}_{2}$ storage, one approach discussed by Burton et al. [47] and Kempka et al. [25] was to reinject captured $\mathrm{CO}_{2}$ into the abandoned UCG reactors. However, we assumed the availability of a geological storage reservoir with sufficient capacity to completely trap the captured $\mathrm{CO}_{2}$ of up to $42 \mathrm{Mt}$ during a 20-year operational lifetime. In the present study, this storage reservoir was assumed to be close to the UCG site at a depth of about $800 \mathrm{~m}$, considered as minimum depth to ensure economic storage [47].

\subsubsection{Onshore CCS/CCU Costs}

Selexol capture costs referring to UCG-based electricity production were determined according to data on energy consumption $\left(0.108 \mathrm{kWh} / \mathrm{kg} \mathrm{CO}_{2}\right.$ [41]), chemical process simulation results on power demand for $\mathrm{CO}_{2}$ compression, as well as Selexol CAPEX $(0.67 € / \mathrm{kW})$ and OPEX $(0.10 € / \mathrm{kW})$ adapted from Mohammed et al. [41]. Scaled to the dimensions of the underlying operational setup (net power generation $100 \mathrm{MW}_{e l}$ ) with emissions of about $0.6 \mathrm{t} \mathrm{CO}_{2} / \mathrm{MWh}$, the total energy demand for CCS summed up to $22 \mathrm{MW}$. Due to the assumed short distance between the UCG site and $\mathrm{CO}_{2}$ storage reservoir, intermediate $\mathrm{CO}_{2}$ compression was not considered. As levelized costs for 
transportation $(0.002 € / \mathrm{t} \mathrm{CO}$ ) have no relevant impact on total levelized CCS costs, they were neglected in this study. Taking into account one well for $\mathrm{CO}_{2}$ injection, CAPEX for injection amounted to $1.57 \mathrm{M} €$ and OPEX to $0.31 \mathrm{M} € /$ year, summing up to total levelized $\mathrm{CO}_{2}$ injection and storage costs of $0.48 € / \mathrm{t} \mathrm{CO}_{2}$. The estimated discounted monitoring costs for a 40 -year period (20 years operational lifetime and additional 20 years for post-closure monitoring) were taken from the "Characterization of European $\mathrm{CO}_{2}$ storage" (SiteChar) project report [48] and amounted to $28 \mathrm{M} €(0.79 € / \mathrm{t} \mathrm{CO}$ ). Cumulative levelized CCS costs (cf. Table 10), considering the underlying boundary conditions applied for the electricity generation setup, amounted to about $15 € / \mathrm{t} \mathrm{CO}_{2}$.

Table 10. Levelized costs for the reference scenario (electricity generation setup) in terms of onshore Selexol capture, injection, storage, and monitoring considering an emission rate of $2.2 \mathrm{t} \mathrm{CO}_{2} / \mathrm{t}$ coal.

\begin{tabular}{lc}
\hline Selexol Capture Cost & Value \\
\hline Energy costs $(€ / \mathrm{MWh})$ & 3.97 \\
Selexol CAPEX $(€ / / \mathrm{MWh})$ & 6.71 \\
Selexol OPEX $(€ / / \mathrm{MWh})$ & 1.00 \\
\hline $\mathrm{CO}_{2}$ Storage Costs & Value \\
\hline Injection and storage costs $(€ / / \mathrm{MWh})$ & 1.06 \\
Monitoring costs $(€ / / \mathrm{MWh})$ & 1.91 \\
\hline Total levelized CCS costs $(€ / / \mathrm{MWh})$ & $\mathbf{1 4 . 6 5}$ \\
\hline
\end{tabular}

Methanol output of about $490 \mathrm{kt}$ methanol per year was accompanied by a total $\mathrm{CO}_{2}$ production of almost $88 \mathrm{~kg} \mathrm{CO} 2 / \mathrm{s}$ resulting from UCG, power generation, in addition to a $\mathrm{CO}_{2}$ mass flow of $0.58 \mathrm{~kg} / \mathrm{s}$ purged during methanol synthesis. Deducting the amount of $22.4 \mathrm{~kg} / \mathrm{s} \mathrm{CO}_{2}$ required for methanol synthesis resulted in an excess $\mathrm{CO}_{2}$ stream of $65 \mathrm{~kg} / \mathrm{s}$, whereby $26 \%$ of $\mathrm{CO}_{2}$ produced throughout the entire UCG-MeOH production chain was utilized. Consequently, carbon capture and its subsequent utilization offer a new economy for $\mathrm{CO}_{2}$, since captured $\mathrm{CO}_{2}$ does not have to be considered as a waste product, only, but is required as a raw material for other processes [17]. In the present study, costs for pre-combustion $\mathrm{CO}_{2}$ capture and utilization (CCU) that arise in line with methanol synthesis were not charged separately. Thus, $\mathrm{CO}_{2}$ capture costs considering the PSA process were associated with hydrogen production CAPEX and OPEX (cf. Section 3.2.1, Table 15), since carbon dioxide was purified from the synthesis gas as by-product of hydrogen. Costs for capturing $\mathrm{CO}_{2}$ that result from internal power supply, its compression before entering the methanol recycle loop, as well as costs for excess $\mathrm{CO}_{2}$ pre-injection compression, injection, and storage were part of the methanol synthesis process and thus charged directly with levelized costs ( $9 \%$ on overall levelized costs). The power requirement to compress the excess $\mathrm{CO}_{2}(65 \mathrm{~kg} / \mathrm{s})$ before storage amounted to about $23 \mathrm{MW}$.

As for methanol synthesis, PSA $\mathrm{CO}_{2}$ capture costs in line with ammonia production were not charged separately, but associated with hydrogen costs (cf. Section 3.3). The power required to compress the $\mathrm{CO}_{2}$ mass flow $(55 \mathrm{~kg} / \mathrm{s}$ ) before storage was determined by chemical process simulations and amounts to about $19 \mathrm{MW}$. As for the electricity generation model setup, $\mathrm{CO}_{2}$ transportation costs were neglected in this study. Taking into account the boundary conditions for the ammonia model setup, costs for $\mathrm{CO}_{2}$ capture resulting from internal power supply, $\mathrm{CO}_{2}$ pre-injection compression, as well as injection, storage, and monitoring summed up to about $18 € / \mathrm{t}$ ammonia.

\subsubsection{Offshore CCS/CCU Costs}

Since offshore electricity generation was not considered in the present study, offshore CCS costs arise from offshore methanol and ammonia production, only. Hereby, similar assumptions referring to monitoring were taken into account to maintain comparability with the onshore models. Thus, related cost positions were identical in the onshore and offshore scenarios. Furthermore, we used identical assumptions for the $\mathrm{CO}_{2}$ storage reservoir in all models. However, assuming five times higher injection 
well drilling costs than in the onshore scenario, total annualized capital, and operational costs for injection and monitoring were about $100 \mathrm{k} €$ higher for all offshore model setups.

\subsection{Methanol Production Energy Balance}

In line with the assessment related to the economic competitiveness of UCG-based methanol on the European market, mass and energy flows, as well as the amount of $\mathrm{CO}_{2}$ that is not emitted, we considered a commercial-scale methanol production scenario based on UCG synthesis gas at an average scale of already operating $\mathrm{MeOH}$ synthesis plants in Europe. For the present study, we chose to investigate methanol production due to its importance as fuel that is blendable with gasoline, transformable, and blendable with diesel, and applicable in fuel cells. Hereby, existing gasoline distribution and storage infrastructure like pipelines, road tankers, and filling stations would require little modification to operate with methanol. Besides, methanol can function as storage for hydrogen or as a feedstock to synthesize olefins [17,49-51].

Usually, methanol is produced by means of the Fischer-Tropsch process, where $\mathrm{CO}$ and $2 \mathrm{H}_{2}$ react to form $\mathrm{CH}_{3} \mathrm{OH}$ [17]. In the present study, we followed methanol production by direct hydrogenation of $\mathrm{CO}_{2}$ with $\mathrm{H}_{2}$, since $\mathrm{CO}$ contained in the UCG synthesis gas was considered to support the internal power supply. Hereby, direct $\mathrm{CO}_{2}$ hydrogenation with $\mathrm{H}_{2}$ is governed by two reactions taking place in the reactor. While Reaction (1) was the one that produced $\mathrm{MeOH}, \mathrm{CO}$ formed in Reaction (2) was recycled together with unreacted $\mathrm{H}_{2}$ to increase the output, once $\mathrm{MeOH}$ and $\mathrm{H}_{2} \mathrm{O}$ were separated.

$$
\begin{gathered}
\mathrm{CO}_{2}+3 \mathrm{H}_{2} \rightleftharpoons \mathrm{CH}_{3} \mathrm{OH}+\mathrm{H}_{2} \mathrm{O} \\
\mathrm{CO}_{2}+\mathrm{H}_{2} \rightleftharpoons \mathrm{CO}+\mathrm{H}_{2} \mathrm{O}
\end{gathered}
$$

Thermodynamic process simulations to analyze mass and energy flows were implemented using the DWSIM software tool [22], whereby applied boundary conditions and subsequent model validation followed the reference process according to [17,52]. In summary, methanol synthesis consisted of the following process steps. After $\mathrm{CO}_{2}$ pressure was increased from 1 bar up to $23.2 \mathrm{bar}, \mathrm{H}_{2}$ ( $30 \mathrm{bar}$, $\left.25{ }^{\circ} \mathrm{C}\right)$ and $\mathrm{CO}_{2}\left(23.2 \mathrm{bar}, 28{ }^{\circ} \mathrm{C}\right)$ feeds were mixed, compressed to 76.4 bar and heated by a heat exchanger to $210^{\circ} \mathrm{C}$ before the reactor inlet. Hereby, the reactor was modeled as an adiabatic Gibbs reactor. The high temperature was crucial, even though the methanol yield had an inverse dependence on temperature and a positive dependence on pressure. However, the catalyst efficiency was more intense at higher temperatures [49]. At the reactor outlet, before methanol and water were separated in a component separator, stream temperature was cooled down from $294{ }^{\circ} \mathrm{C}$ to $35{ }^{\circ} \mathrm{C}$ in a heat exchanger. About $99 \%$ of unreacted $\mathrm{H}_{2}, \mathrm{CO}_{2}$, and $\mathrm{CO}$ was recycled, whereby $1 \%$ is purged to avoid accumulation of inert gases [17]. In the present study, total electricity consumption for the synthesis of $489 \mathrm{kt} \mathrm{MeOH}$ /year resulted from the power demand for $\mathrm{CO}_{2} / \mathrm{H}_{2}$ compression (34.4 MW), as well as methanol and water separation (1.4 MW). Additional heat exchanged among the streams amounted to 71.2 MW, compared to $81 \mathrm{MW}$ according to Perez et al. [17]. This heat can be further used to generate electricity; however, in order not to exceed the focus of this study, we did not consider conversion of surplus heat into electricity in our simulations. Compared to identical model boundary conditions applied by Perez et al. [17], compression power demand in the present study was about twice as high. This significant difference was related to the energy efficient process setup applied by Perez et al. [17], using electricity generated by ad hoc steam turbine systems, as well as four expanders that take advantage of the calorific value of the purge gases. In this way, electricity demand can be reduced by $46 \%$ [17]. Consequently, considering the utilization of the heat produced, power demand in the present study offered opportunities to be significantly optimized. Discrepancy in the methanol production rate of our model implementation compared to Perez et al. [17] amounted to $1.6 \%$. This was likely attributable to the application of different reactor types (Gibbs reactor versus plug flow reactor) in both studies. Besides, we did not apply any catalysts, whereby Perez et al. [17] used a productive copper catalyst $\left(\mathrm{Cu} / \mathrm{ZnO} / \mathrm{Al}_{2} \mathrm{O}_{3}\right)$. 
Combining thermodynamic process simulations to quantify the energy balance of methanol synthesis with the techno-economic process model, gross power generation for the entire UCG-MeOH production chain including air and gasification agent compression, $\mathrm{CO}_{2}$ capture after electricity generation, as well as methanol synthesis summed up to $609 \mathrm{MW}$. Hereby, the gross generation and thus the overall model setup was adjusted iteratively to provide the required $\mathrm{H}_{2}$ amount of at least $3.05 \mathrm{~kg} / \mathrm{s}$ in the synthesis gas mass flow, so that the envisaged methanol output of $15.5 \mathrm{~kg} \mathrm{MeOH} / \mathrm{s}$ was achieved. The electric power output not required for methanol production summed up to about $128 \mathrm{MW}_{e l}$ and can be fed into the local power grid. As a result of $\mathrm{H}_{2}$ consumption for methanol production, the excess synthesis gas $\mathrm{CV}$ was decreased by about $28 \%$.

\subsection{Ammonia Production Energy Balance}

Ammonia is a key ingredient for fertilizer production, whereby the widespread use of ammonia in agriculture was initiated by the "green revolution", which also involved development of high-yield crops and advances in pesticides. Thus, ammonia synthesis optimization is a topic of high interest in the industry, as the market continues to expand and demand increases [53]. Ammonia is produced from hydrogen and nitrogen at operating pressures above 100 bar (Haber-Bosch process), necessary to achieve a high reaction rate [53]. Reduction of expenses for the required compression power can be achieved by the implementation of compressors driven by steam turbines that take advantage of steam produced elsewhere in the process, as applied in the methanol model. According to the approach of Villesca et al. [53], compression power reduction during ammonia synthesis was achieved by increasing reactor efficiency through the use of an innovative high activity ruthenium-based synthesis catalyst being twenty times more active than conventional iron catalysts, so that lower synthesis pressures and temperatures can be applied.

For the assessment of costs, mass, and energy flows in view of ammonia production, we chose an average scale of existing ammonia plants in Poland with a production rate of about $314 \mathrm{kt} /$ year [53]. The DWSIM ammonia synthesis model was parametrized according to the optimized process setup by Villesca et al. [53] and scaled to the envisaged output. Hereby, hydrogen and nitrogen derived from the UCG synthesis gas along with small fractions of methane and argon were compressed from 20 bar up to 100 bar and fed to the ammonia process at a molar ratio of 3:1. Mixed with yet not reacted components entrained in a recycling process, nitrogen and hydrogen entered the synthesis reactor at a pressure of $100 \mathrm{bar}$ and at the temperature of $11^{\circ} \mathrm{C}$. The reactor was modeled as an adiabatic Gibbs reactor, governed by the exothermic equilibrium Reaction (3). The stream (vapor phase) left the reactor at a temperature of $375^{\circ} \mathrm{C}$ and was cooled down to $-30{ }^{\circ} \mathrm{C}$ before the end-product ammonia was separated. Unreacted components $\left(\mathrm{H}_{2}, \mathrm{~N}_{2}\right)$, making up less than $1 \%$ of the purge stream, were recycled to increase the ammonia yield.

$$
\mathrm{N}_{2}+3 \mathrm{H}_{2} \Leftrightarrow 2 \mathrm{NH}_{3}
$$

Before being scaled to the applied dimensions, our simulation results exhibited just insignificant differences of about $1 \%$ compared to the ammonia yield achieved by Villesca et al. [53]. Waste heat resulting from the heat exchanged between the product streams amounted to $29 \mathrm{MW}$. The total power demand for ammonia synthesis summed up to about $26 \mathrm{MW}$, where about $99 \%$ was required for fluid compression. Villesca et al. [53] did not present the total power requirement for ammonia synthesis. However, compared to the findings on different ammonia synthesis loop efficiencies [54], our energy balance simulation results appeared to be representative. To determine finally the economic competitiveness of UCG-based $\mathrm{NH}_{3}$ production on the European market, thermodynamic simulation results on the power required to synthesize ammonia were integrated into the techno-economic model by Nakaten et al. [55]. Thus, taking into account all process steps related to the entire UCG-NH production chain, the required gross generation added up to about $382 \mathrm{MW}$. Hereby, the gross generation was iteratively adjusted in order to provide at least $1.91 \mathrm{~kg} / \mathrm{s} \mathrm{H}_{2}$ within the synthesis 
gas mass flow, necessary to achieve the envisaged ammonia output. The generated electric output not required for ammonia production summed up to about $66 \mathrm{MW}_{e l}$ and can be fed into the local power grid. Excess synthesis gas $\mathrm{CV}$ was up to $28 \%$ lower than the initial one, as $100 \% \mathrm{of}_{2} \mathrm{H}_{2}$ from the synthesis gas was consumed to synthesize ammonia.

\section{Results}

In the present section, we discuss the techno-economic calculation results for UCG-based electricity, methanol, and ammonia production.

\subsection{Levelized UCG-CCGT-CCS Costs}

Costs of electricity (COE) are the total costs required for conversion of a fuel into electricity. For the current study, we used the COE calculation according to Nakaten et al. [5], based on UCG synthesis gas electrification in a combined cycle gas turbine power plant (CCGT) with an efficiency of $58 \%$ and a power output of $100 \mathrm{MW}_{e l}$. The calculated gross power generation amounted to $286 \mathrm{MW}$ in the reference scenario. Hereby, gross power generation for all electricity production model setups was automatically adjusted to the energy demand that changes with the underlying synthesis gas composition, while power output was maintained constant at $100 \mathrm{MW}_{e l}$ to ensure comparability between the different scenarios assessed within the sensitivity analysis. Further power plant-related boundary conditions that were considered within the economic assessment were a calculated interest rate on the planning horizon of $7.5 \%$ and a real operating cost increase of $1.5 \%$. Electricity production costs were calculated as the average costs on a full-cost basis, and all costs were adapted to the reference year 2018. Equations to determine total investment costs, annual capital costs, operating costs, the capital value of the overall costs, and the levelized total annual costs with and without demolition were taken from Nakaten et al. [5], Hillebrand [32], and Schneider [33]. Synthesis gas costs contained all UCG-related costs, such as gasification agent production and injection, synthesis gas processing, drilling, land acquisition, piping-, measuring-, control equipment costs, as well as concession fees. The levelized synthesis gas costs $(4.6 € / \mathrm{GJ})$ were calculated by dividing UCG costs by the amount of synthesis gas produced ( $9 \mathrm{PJ} /$ year). All above-mentioned cost positions, relevant for the determination of COE (32.2€/MWh), were shown in Table 11. Hereby, COE was the quotient of the levelized total annual costs and the amount of electricity produced (1.5 TWh/year). In summary, COE and CCS costs summed up to $46.9 € /$ MWh. Compared to COE of other Polish power plants amounting to $45-75 € / \mathrm{MWh}$ without $\mathrm{CO}_{2}$ emission charges [56-60] and to $91 € / \mathrm{MWh}$ for gas-fired power plants with $\mathrm{CO}_{2}$ emission charges [57], the application of UCG synthesis gas for electricity production was competitive at the Polish energy market. Offshore electricity production was not considered in the present study. However, considering the same amount of synthesis gas produced as in the related onshore model (286 MW gross power generation), offshore synthesis gas production costs would be about twice as high.

Table 11. Costs of all integrated UCG and CCGT process stages for 20 years of operation, combined as levelized costs of electricity (COE).

\begin{tabular}{lc}
\hline Cost Position & Value \\
\hline CCGT investment costs $(\mathrm{M} €)$ & 30.3 \\
CCGT interest payments $(\mathrm{M} €)$ & 20.2 \\
CCGT fixed operating costs $(\mathrm{M} €)$ & 24.5 \\
CCGT variable operating costs $(\mathrm{M} €)$ & 8.2 \\
UCG synthesis gas production costs $(\mathrm{M} €)$ & 832.7 \\
CCGT levelized total annual costs with demolition $(\mathrm{M} €)$ & 0.9 \\
\hline Total costs (M€) & $\mathbf{9 1 6 . 8}$ \\
\hline Levelized UCG-CCGT costs of electricity (€/MWh) & $\mathbf{3 2 . 2}$ \\
\hline
\end{tabular}




\subsection{Levelized UCG-MeOH-CCU Costs}

\subsubsection{Onshore UCG-MeOH-CCU Costs}

Techno-economic process modeling results related to total methanol production costs are listed in Table 12, whereby levelized methanol production costs summed up to $206 € / \mathrm{t} \mathrm{MeOH}$ (cf. Table 13).

Table 12. Cost positions for methanol production process stages, combined as UCG-based methanol production costs for a 20-year operational lifetime (plant size of about $490 \mathrm{kt} /$ year).

\begin{tabular}{|c|c|c|}
\hline CAPEX & Value & Reference \\
\hline Plant equipment, civil work, site preparation $(\mathrm{M} €)$ & 72.2 & [17] \\
\hline Staff (engineering) costs, infrastructure modification $(\mathrm{M} €)$ & 38.9 & [17] \\
\hline Further costs for plant designing, constructing, building (M€) & 66.7 & [17] \\
\hline Working capital $(\mathrm{M} €)$ & 22.2 & [17] \\
\hline $\mathrm{CO}_{2} / \mathrm{H}_{2}$ provision by PSA $(\mathrm{M} €)$ & 34.0 & [31] \\
\hline Total CAPEX $(\mathrm{M} €)$ & 234.0 & Calculated \\
\hline OPEX & Value & Reference \\
\hline Operating labor $(\mathrm{M} €)$ & 34.2 & [17] \\
\hline $\mathrm{CO}_{2} / \mathrm{H}_{2}$ provision by PSA $(\mathrm{M} €)$ & 340.2 & [31] \\
\hline Process water, other materials $(\mathrm{k} €$ ) & 22.8 & [17] \\
\hline Total OPEX $(\mathrm{M} €)$ & 397.2 & Calculated \\
\hline Total UCG costs excluding PSA $(\mathrm{M} €)$ & 1368.1 & Calculated \\
\hline Total costs for $\mathrm{CO}_{2}$ injection, storage, monitoring $(\mathrm{M} €$ ) & 35.1 & {$[48,61]$} \\
\hline Total MeOH synthesis costs including UCG $(\mathrm{M} €)$ & 2034.4 & Calculated \\
\hline
\end{tabular}

Compared to the average European market price of $419 €$ per tonne $\mathrm{MeOH}$ in 2018 [62], UCG-based methanol production was competitive. Costs for the production of synthesis gas in line with onshore methanol production amounted to $4.5 € / \mathrm{GJ}$. Costs for $\mathrm{CO}_{2}$ compression, injection, storage, and monitoring summed up to about $14 € / \mathrm{t} \mathrm{MeOH}$. The share of individual cost positions on total levelized onshore methanol production costs is shown in Table 13.

Table 13. Share of individual cost positions on levelized onshore UCG-based methanol production costs for 20 years of operation.

\begin{tabular}{lcc}
\hline Cost Position & Costs (€/t MeOH) & Percentage Share (\%) \\
\hline Total drilling costs & 8.3 & 4.0 \\
Fees, land acquisition, piping, measuring, control equipment & 67.6 & 32.9 \\
Synthesis gas processing & 44.2 & 21.5 \\
Gasification agent production (ASU) and injection & 85.7 & 41.6 \\
\hline Total levelized costs/total percentage & $\mathbf{2 0 5 . 8}$ & $\mathbf{1 0 0 . 0}$ \\
\hline
\end{tabular}

\subsubsection{Offshore UCG-MeOH-CCU Costs}

Offshore UCG-based methanol production costs were composed of all UCG-related process costs taken into account for the onshore model, as well as the aforementioned CAPEX and OPEX for the offshore platform. Hereby, total levelized offshore methanol production costs exceeded the onshore costs by $64 \%$ (cf. Table 14). Nevertheless, compared to the current methanol market price, offshore methanol production was yet economically competitive. Synthesis gas production costs under the given boundary conditions summed up to $7.4 € / G J$. The share of the main cost positions on total levelized UCG-based offshore methanol production costs is shown in Table 14. 
Table 14. Share of individual cost positions on levelized offshore UCG-based methanol production costs for 20 years of operation.

\begin{tabular}{lcc}
\hline Cost Position & Costs (€/t MeOH) & Percentage Share (\%) \\
\hline Total drilling costs & 8.9 & 2.8 \\
Offshore platform, piping, measuring, control equipment & 189.2 & 58.7 \\
Synthesis gas processing & 42.2 & 13.1 \\
Gasification agent production (ASU) and injection & 81.9 & 25.4 \\
\hline Total levelized costs/total percentage & $\mathbf{3 2 2 . 2}$ & $\mathbf{1 0 0 . 0}$ \\
\hline
\end{tabular}

\subsection{Levelized UCG-NH3-CCS Costs}

\subsubsection{Onshore UCG-NH $3-\mathrm{CCS}$ Costs}

Ammonia synthesis costs (cf. Table 15) were adapted from Bartels [63] and scaled to the dimensions of the present study.

Table 15. Ammonia production CAPEX/OPEX for 20 years of operation (plant size of $314 \mathrm{kt} /$ year).

\begin{tabular}{lcc}
\hline Cost Position & Value & Reference \\
\hline Capital charge without ASU/gas turbine $(\mathrm{M} €)$ & 461.5 & {$[63]$} \\
Haber-Bosch synthesis loop $(\mathrm{M} €)$ & 131.7 & {$[63]$} \\
Costs for injection, storage, and monitoring $(\mathrm{M} €)$ & 34.6 & {$[48,61]$} \\
Total UCG costs with PSA $(\mathrm{M} €)$ & 1241.6 & Calculated \\
\hline Total $\mathrm{NH}_{3}$ synthesis costs including UCG $(\mathrm{M} €)$ & $\mathbf{1 8 6 9 . 4}$ & Calculated \\
\hline
\end{tabular}

Adding total UCG costs related to the underlying model setup, total levelized ammonia production costs cumulated to about $298 € / \mathrm{t} \mathrm{NH}_{3}$ (cf. Table 16). Costs for $\mathrm{CO}_{2}$ injection, storage, and monitoring summed up to about $18 € / \mathrm{t} \mathrm{NH}_{3}$. Synthesis gas production costs accompanying onshore ammonia synthesis amounted to $5.2 € / \mathrm{GJ}$. Compared to the current European ammonia market price for 2018 with $320 € / \mathrm{t} \mathrm{NH}_{3}$ [64], UCG-based ammonia production was economically competitive. The share of individual cost positions on total levelized onshore ammonia production costs is shown in Table 16.

Table 16. Share of individual cost positions on levelized onshore ammonia production costs.

\begin{tabular}{lcc}
\hline Cost Position & Costs $\left(€ / \mathbf{t} \mathbf{N H}_{3}\right)$ & Percentage Share (\%) \\
\hline Total drilling costs & 10.4 & 3.5 \\
Fees, land acquisition, piping, measuring, control equipment & 107.7 & 36.2 \\
Synthesis gas processing & 56.2 & 18.8 \\
Gasification agent production (ASU) and injection & 123.5 & 41.5 \\
\hline Total levelized costs/total percentage & $\mathbf{2 9 7 . 8}$ & $\mathbf{1 0 0 . 0}$ \\
\hline
\end{tabular}

\subsubsection{Offshore UCG-NH$H_{3}$-CCS Costs}

The setup for offshore ammonia production was equal to that used in the onshore scenarios. Thus, costs for the onshore and offshore ammonia synthesis processes were the same. However, due to higher CAPEX and OPEX for the technical offshore equipment, five times higher drilling costs compared to the onshore scenarios, as well as the application of a different UCG exploitation scheme in the offshore scenarios, offshore ammonia production was $60 \%$ more expensive than its onshore variant (cf. Table 17). Synthesis gas production accompanying offshore ammonia production amounted to $10 € /$ GJ. Compared to the average European ammonia market price, offshore UCG-based ammonia production was not competitive. Table 17 lists the share of main cost positions on total levelized UCG-based offshore ammonia production costs. 
Table 17. Share of individual cost positions on levelized offshore ammonia production costs.

\begin{tabular}{lcc}
\hline Cost Position & Costs $\left(€ / \mathbf{t} \mathbf{N H}_{3}\right)$ & Percentage Share (\%) \\
\hline Total drilling costs & 9.3 & 1.9 \\
Offshore platform, piping, measuring, control equipment & 323.6 & 66.9 \\
Synthesis gas processing & 47.1 & 9.7 \\
Gasification agent production (ASU) and injection & 103.5 & 21.5 \\
\hline Total levelized costs/total percentage & $\mathbf{4 8 3 . 5}$ & $\mathbf{1 0 0 . 0}$ \\
\hline
\end{tabular}

\subsection{Sensitivity Analysis}

We applied a one-at-a-time (OAT) sensitivity analysis to assess uncertainties related to the UCG synthesis gas end-utilization option costs. This kind of sensitivity analysis was used to assess the range of possible outcomes imposed by the variation of one model input parameter across a plausible range of uncertainty. Hereby, the focus was on quantifying the influence of single model input parameters on overall costs to, e.g., assess which process steps benefit most from optimization. In the underlying study, we further investigated the impact of different synthesis gas compositions and calorific values, as well as gasification agent compositions for the onshore realization. For offshore realization, uncertain model input data such as offshore drilling costs and the maximum achievable gasification channel width were considered in view of the well design.

\subsubsection{Impact of Synthesis Gas Composition, CV, and Gasification Agent Compositions on Total Costs}

We further investigated the impact of different synthesis gas compositions and related CVs, as the CV impacts UCG synthesis gas end-utilization options in view of its economical suitability for commercialization. Besides, $\mathrm{CV}$ is one of the parameters that can be controlled with little effort as even minor modifications of the model assumptions may induce its increase or decrease by, e.g., different applied gasification agent compositions and gasification stages $[65,66]$. To analyze potential cost variations, we focused on four synthesis gas compositions (cf. Table 18). The chosen compositions were derived from in-situ and ex-situ gasification tests at the Wieczorek mine and ex-situ tests on coals sampled at the Bielszowice mine, whereby different gasification agent compositions at varying $\mathrm{p} / \mathrm{T}$ conditions were investigated [8]. In order to maintain a site-specific techno-economic assessment in the sensitivity analysis, we implemented two scenarios with data directly related to the selected target area (Scenarios I and II). Furthermore, two scenarios representing the results of gasification tests on coals from the Bielszowice mine (Scenarios III and IV) were included into the analysis due to the availability of extensive analysis data. The considered synthesis gas compositions exhibited significant differences in their $\mathrm{CO}_{2}$ content, $\mathrm{CV}$, and UCG-to-synthesis gas conversion efficiency. Thus, the chosen synthesis gas compositions allowed quantifying the impact of the parameters expected to have a major impact on the total levelized costs.

Table 18. Synthesis gas compositions and calorific values investigated in one-at-a-time sensitivity analyses; values given in \% by volume; data derived from Stańczyk et al. [8,10]; CVs calculated.

\begin{tabular}{llllllll}
\hline Scenario & $\begin{array}{l}\mathrm{CO}_{2} \\
(\%)\end{array}$ & $\begin{array}{l}\mathbf{H}_{2} \\
\mathbf{( \% )}\end{array}$ & $\begin{array}{l}\mathbf{N}_{2} \\
(\mathbf{\%})\end{array}$ & $\begin{array}{l}\mathrm{CH}_{4} \\
\mathbf{( \% )}\end{array}$ & $\begin{array}{l}\mathrm{CO} \\
(\mathbf{\%})\end{array}$ & $\begin{array}{l}\mathbf{C V} \\
\left(\mathbf{M J} / \mathbf{s m}^{3}\right.\end{array}$ & $\begin{array}{l}\text { Oxidizer } \\
\text { Composition (\%) }\end{array}$ \\
\hline Wieczorek (I) & 6.4 & 15.9 & 58.9 & 1.2 & 17.5 & 4.4 & $\mathrm{O}_{2}: 35, \mathrm{~N}_{2}: 65$ \\
Wieczorek (II) & 9.2 & 10.7 & 63.7 & 2.0 & 14.5 & 3.7 & Air: 100 \\
Bielszowice (III) & 14.8 & 11.9 & 60.1 & 2.8 & 10.4 & 3.6 & Air: 100 \\
Bielszowice (IV) & 23.2 & 18.9 & 36.2 & 4.2 & 17.5 & 5.8 & $\mathrm{O}_{2}: 51.3, \mathrm{~N}_{2}: 48.7$ \\
\hline
\end{tabular}

Onshore UCG-CCGT-CCS Scenario

OAT sensitivity analysis results showed that cost effectiveness in the electricity generation scenarios was rather dominated by technical constraints (power plant net capacity, gasification 
agent production) than by geological or chemical boundary conditions, such as the synthesis gas CV and UCG-to-synthesis gas conversion efficiency. UCG-to-synthesis gas conversion efficiency was determined by synthesis gas and coal CVs, as well as the theoretical synthesis gas-to-coal ratio, whereby the theoretical synthesis gas-to-coal ratio was the ratio of the carbon content in the coal and that in the synthesis gas. Data on the coal carbon content and that in the tars for the Wieczorek and Bielszowice coal types taken into account were provided by Stańczyk et al. [8,10] and Mocek et al. [67]. Thus, despite the high CV (cf. Table 18) and the highest UCG-to-synthesis gas conversion efficiency achieved among the CCGT scenarios (cf. Table 19), costs for electricity generation and CCS in Scenario I exceeded those calculated for the other three scenarios by $11-37 \%$. The notable cost increase in Scenario I compared to the other scenarios was attributable to the high oxygen share in the gasification agent resulting in high ASU costs and to the lowest installed net capacity in that scenario. Thus, although ASU costs in Scenario IV exceeded those in Scenario I, the higher installed net capacity induced an overall cost decrease by up to $2.7 \%$. Hereby, the installed net capacities for the different scenarios were iteratively adjusted to the energy requirement of all process steps involved, while a previously-determined fixed electrical power output of $100 \mathrm{MW}_{e l}$ was maintained for comparability. With regard to the four investigated scenarios, the synthesis gas composition most suitable for electricity generation was represented by Scenario III. The benefit of gasification with pure air (cf. Table 18) and the relatively high installed net power capacity overcame the disadvantages associated with the low synthesis gas CV and UCG-to-synthesis gas conversion efficiency. Synthesis gas production costs for electricity generation are listed in Table 19. Cost effectiveness of the energy-intensive $\mathrm{CO}_{2}$ capture correlated with the available $\mathrm{CO}_{2}$ amount in the given synthesis gas composition. Since the synthesis gas composition in Scenario I showed the lowest $\mathrm{CO}_{2}$ and $\mathrm{CO}$ ratios among the CCGT scenarios, CCS costs for Scenario I were about 26 to $34 \%$ above those for the other scenarios.

In summary, the OAT sensitivity analysis revealed that under the given model assumptions and even in the case of the assumed worst-case conditions in Scenario I, the application of UCG synthesis gas for electricity production was competitive for the Polish energy market.

Table 19. One-at-a-time sensitivity analysis results for the onshore UCG-CCGT-CCS scenario considering different synthesis gas compositions and calorific values.

\begin{tabular}{lllllllll}
\hline Scenario & $\begin{array}{l}\text { COE } \\
(€ / M W h)\end{array}$ & $\begin{array}{l}\text { CCS Costs } \\
(€ / \text { MWh) }\end{array}$ & $\begin{array}{l}\text { Synthesis Gas } \\
\text { Costs }(€ / G J)\end{array}$ & $\begin{array}{l}\text { UCG Synthesis } \\
\text { Gas Efficiency (MJ/MJ) }\end{array}$ & $\begin{array}{l}\mathbf{P}_{\text {gross }} \\
(\mathbf{M W )}\end{array}$ & $\begin{array}{l}\mathbf{P}_{\text {units }} \\
(\mathbf{M W})\end{array}$ & $\begin{array}{l}\mathbf{P}_{\text {el }} \\
(\mathbf{M W})\end{array}$ & $\begin{array}{l}\mathbf{P}_{\text {net }} \\
(\mathbf{M W})\end{array}$ \\
\hline I & 32.2 & 14.7 & 4.7 & 0.84 & 285 & 66 & 100 & 166 \\
II & 20.8 & 10.9 & 2.8 & 0.70 & 374 & 117 & 100 & 217 \\
III & 19.7 & 9.7 & 2.6 & 0.53 & 500 & 191 & 100 & 291 \\
IV & 31.5 & 10.4 & 4.5 & 0.53 & 411 & 138 & 100 & 238 \\
\hline
\end{tabular}

$\mathrm{P}_{\text {gross }}=$ total gross power generation, $\mathrm{P}_{\text {units }}=$ power required to operate all integrated process units, $\mathrm{P}_{e l}=$ electric power output, $\mathrm{P}_{\text {net }}=$ net power generation consisting of $\mathrm{P}_{\text {units }}$ and $\mathrm{P}_{e l}$.

\section{Onshore UCG-MeOH-CCU Scenario}

While high oxygen contents in the gasification agent were favorable by increasing the overall synthesis gas CV, the UCG-to-synthesis gas conversion efficiency was reduced, since more carbon, and thus more coal, was required to maintain a consistent synthesis gas mass flow. From an economic point of view, air separation and compression increased the required power demand, and thus gross power generation and related costs significantly, whereby the resulting methanol yield remained unchanged. Gross power generation in the methanol scenarios was iteratively adjusted to cover the required $\mathrm{H}_{2}$ amount $(3.05 \mathrm{~kg} / \mathrm{s}$ ) in the underlying synthesis gas composition, as well as the resulting energy requirement of all process steps involved. Despite the high $\mathrm{H}_{2}$ content in the synthesis gas (cf. Table 18), Scenario IV represented the worst case with costs of $268 € / \mathrm{t}$ methanol induced by a share of about $36 \%$ ASU costs on overall costs and a low UCG-to-synthesis gas conversion efficiency. Due to $\mathrm{H}_{2}$ utilization in the methanol synthesis, the synthesis gas CV in Scenario IV was reduced from initially 5.8 to $4.6 \mathrm{MJ} / \mathrm{sm}^{3}$. Among the four investigated synthesis gas compositions, the one most suitable 
for methanol production was that in Scenario III. With regard to Scenario II, where air separation was not required and even more favorable geological and chemical boundary conditions were given, the gross power generation was $127 \mathrm{MW}$ above that in the best case. This resulted in higher CAPEX and OPEX, while the methanol production rate was constant. Nevertheless, one option to increase the competitiveness of Scenario II compared to the best case is to make use of excess electric power output, which was not required for methanol production in Scenario II $\left(116 \mathrm{MW}_{e l}\right)$. However, the impact of cost revenues for providing surplus energy to the public was not considered in the underlying study. Synthesis gas production costs that occur in the context of methanol production are listed in Table 20. The lowest levelized synthesis gas production costs were achieved in Scenario II because of the high gross power generation, the increased synthesis gas mass flow rate, and a higher installed net power capacity. Taking into account the amount of $\mathrm{CO}_{2}$ that is required for hydrogenation in comparison to the amount of excess $\mathrm{CO}_{2}$, Scenario I represented the best $\mathrm{CO}_{2}$ utilization rate for the investigated scenarios (cf. Table 20).

Table 20. One-at-a-time sensitivity analysis results for the onshore UCG-MeOH-CCU scenario considering different synthesis gas compositions and calorific values.

\begin{tabular}{|c|c|c|c|c|c|c|c|c|c|}
\hline Scenario & $\begin{array}{l}\text { Levelized } \\
\text { Costs }(€ / t)\end{array}$ & $\begin{array}{l}\text { Synthesis } \\
\text { Gas Costs }(€ / G J)\end{array}$ & $\begin{array}{l}\text { Excess CV } \\
\left(\mathrm{MJ} / \mathrm{sm}^{3}\right)\end{array}$ & $\begin{array}{l}\text { UCG synthesis } \\
\text { Gas Efficiency (MJ/MJ) }\end{array}$ & $\begin{array}{l}\text { Utilized } \\
\mathrm{CO}_{2}(\%)\end{array}$ & $\begin{array}{l}\text { Pgross } \\
\text { (MW) }\end{array}$ & $\begin{array}{l}P_{\text {units }} \\
\text { (MW) }\end{array}$ & $\begin{array}{l}\mathbf{P}_{\mathrm{el}} \\
(\mathrm{MW})\end{array}$ & $\begin{array}{l}P_{\text {net }} \\
\text { (MW) }\end{array}$ \\
\hline I & 205.8 & 4.5 & 3.2 & 0.61 & 25.5 & 609 & 226 & 128 & 354 \\
\hline II & 189.8 & 2.9 & 2.9 & 0.54 & 16.4 & 869 & 388 & 116 & 504 \\
\hline III & 177.8 & 3.1 & 2.7 & 0.39 & 15.8 & 742 & 429 & 1 & 430 \\
\hline IV & 268.2 & 5.1 & 4.6 & 0.42 & 16.0 & 721 & 358 & 60 & 418 \\
\hline
\end{tabular}

Due to the additionally required coal amount resulting from the lower carbon content of the Bielszowice coals, and thus a lower UCG-to-synthesis gas conversion efficiency, the least appropriate synthesis gas composition in view of $\mathrm{CO}_{2}$ emission mitigation was represented by Scenario III. In summary, OAT sensitivity analysis results showed that for all investigated methanol production scenarios, UCG-based methanol production was profitable and could compete on the Polish market.

\section{Onshore UCG-NH${ }_{3}-\mathrm{CCS}$ Scenario}

As for methanol production, gross power generation in the ammonia scenarios was iteratively adjusted to maintain a $\mathrm{H}_{2}$ mass flow of $1.91 \mathrm{~kg} / \mathrm{s}$ in the synthesis gas composition and the energy requirement. Comparing OAT sensitivity analysis results related to ammonia production economics, the levelized costs of the four selected synthesis gas compositions differed by up to $28 \%$. Hereby, the lowest costs were achieved in Scenarios II and III, whereby Scenario IV represented the worst case. Unlike competitiveness in the context of methanol production, sensitivity analysis results revealed that the most economic ammonia production was achieved in Scenario II (cf. Table 21). For methanol production, geological benefits of Scenario II were overlapped by a significantly higher gross generation, and thus synthesis gas mass flow to cover the required $\mathrm{H}_{2}$ amount. However, in the context of ammonia production, gross power generation in Scenario II exceeded that achieved in Scenario III by 4 MW. However, due to the more favorable coal type considered in Scenario II, synthesis gas mass flow in Scenario II was about $4 \%$ lower than in Scenario III, resulting in slightly lower CAPEX/OPEX. Besides, ammonia production in the best case benefited from the higher installed net capacity for autonomous power supply. Providing surplus energy would further advantage the best case, since excess electric power not required for ammonia production in Scenario II significantly exceeded that of Scenario III. After $\mathrm{H}_{2}$ separation, the synthesis gas $\mathrm{CV}$ in Scenario III was reduced by $23 \%$ compared to the initial CV. With regard to synthesis gas costs, Scenario II showed the most and Scenario IV the least favorable synthesis gas composition. Increased synthesis gas costs in the worst case resulted from high air separation costs. Synthesis gas production competitiveness in the 
best case was rather impacted by the higher installed net capacity than by economies of scale, since the differences in the synthesis gas mass flows in Scenarios II and III were negligible.

In summary, OAT sensitivity analysis results on ammonia production costs showed that except from the underlying assumed worst-case constraints, all onshore UCG-based ammonia production scenarios were competitive with the average European ammonia market price of $320 € / \mathrm{t} \mathrm{NH}_{3}$, [64].

Table 21. One-at-a-time sensitivity analysis results for the onshore UCG- $\mathrm{NH}_{3}$-CCS scenario considering different synthesis gas compositions and calorific values.

\begin{tabular}{|c|c|c|c|c|c|c|c|c|}
\hline Scenario & $\begin{array}{l}\text { Levelized } \\
\text { Costs }(€ / t)\end{array}$ & $\begin{array}{l}\text { Synthesis } \\
\text { Gas Costs (€/GJ) }\end{array}$ & $\begin{array}{l}\text { Excess CV } \\
\left(\mathrm{MJ} / \mathrm{sm}^{3}\right)\end{array}$ & $\begin{array}{l}\text { UCG Synthesis } \\
\text { Gas Efficiency (MJ/MJ) }\end{array}$ & $\begin{array}{l}P_{\text {gross }} \\
\text { (MW) }\end{array}$ & $\begin{array}{l}P_{\text {units }} \\
\text { (MW) }\end{array}$ & $\begin{array}{l}\mathbf{P}_{\mathrm{el}} \\
(\mathrm{MW})\end{array}$ & $\begin{array}{l}P_{\text {net }} \\
\text { (MW) }\end{array}$ \\
\hline I & 297.77 & 5.17 & 3.20 & 0.61 & 382 & 156 & 66 & 222 \\
\hline II & 271.89 & 3.15 & 2.90 & 0.54 & 544 & 257 & 58 & 315 \\
\hline III & 274.18 & 3.20 & 2.70 & 0.41 & 541 & 311 & 3 & 314 \\
\hline IV & 353.60 & 5.60 & 4.60 & 0.42 & 451 & 238 & 23 & 261 \\
\hline
\end{tabular}

Sensitivity analysis results for all assessed UCG-based end products revealed that applying gasification agent oxygen ratios above $30 \%$ by volume, and thus increasing the $\mathrm{CO}_{2}$ share in the resulting synthesis gas, was not favorable from economic and $\mathrm{CO}_{2}$ emission mitigation perspectives. Furthermore, an oxygen ratio above $30 \%$ by volume in the gasification agent was likely to significantly increase abrasion effects in pipelines and well tubings due to the resulting higher flow velocities.

\subsubsection{Variation of Offshore Drilling Costs}

For the assessment of offshore drilling costs, we assumed a 5-(reference scenarios), 10-, and 15 -fold (worst case) cost increase, compared to the drilling costs applied in the onshore calculations. Our calculation results showed that increasing costs for offshore drilling up to the 15-fold induced an almost linear methanol production cost increment by $8.3 € / \mathrm{t} \mathrm{MeOH}$ compared to the offshore reference scenario. The increase in ammonia production costs was also linear and amounted to $7.8 € / \mathrm{t} \mathrm{NH}$. The cost bandwidths for methanol and ammonia production resulting from varying drilling costs were low, since the share of drilling costs on total costs in the offshore reference scenarios was about 3\% for methanol and $2 \%$ for ammonia production. Hereby, the share of offshore drilling costs related to total levelized offshore costs was about $1 \%$ lower than the respective share of onshore drilling costs to total levelized onshore costs. This resulted from the radial shape of the offshore well layout, offering a more optimized design than the applied onshore well layout. However, this design optimization in the offshore scenarios was associated with higher operational risks related to the technical implementation of the P-CRIP approach, which has not yet been as widely applied as the CRIP-based UCG scheme.

\subsubsection{Impact of Technically-Achievable Gasification Channel Width}

Based on the gasification channel width in the reference scenario (200 m, best case), we further assessed costs taking into account channel widths of $50 \mathrm{~m}$ (worst case), $100 \mathrm{~m}$, and $150 \mathrm{~m}$ (at the outer boundary, cf. Figure 7). 


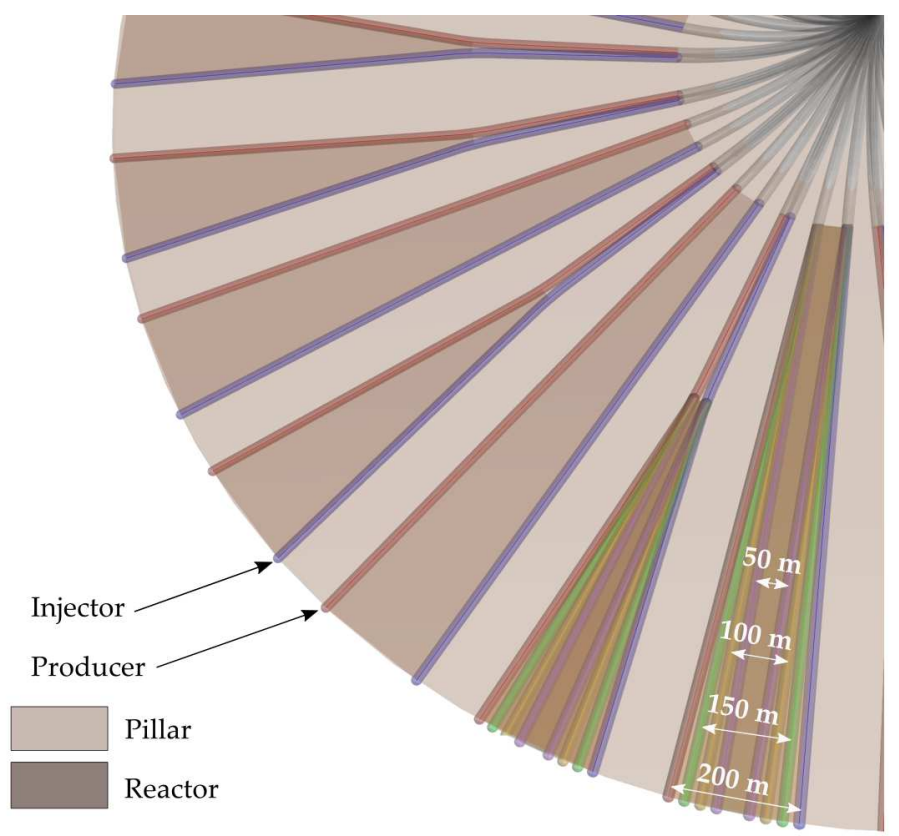

Figure 7. Gasification channel design for different channel widths (50 m-200 m).

In the present study, the model parameter mainly affected by a variation of gasification channel width was the coal yield per gasification channel, also determining the drilling meters. Consequently, drilling costs depended on the number of additional wells to be drilled to maintain the required daily coal supply when channel width was decreasing. OAT sensitivity analysis results listed in Table 22 showed that varying the gasification channel width in the offshore methanol and ammonia production scenarios by $150 \mathrm{~m}$ caused a difference in drilling meters of up to $68 \%$. However, this obviously significant difference in drilling meters induced only a minor difference in the total levelized methanol $(7.5 \%)$ and ammonia (4.3\%) production costs due to the low impact of drilling costs on total offshore UCG-based end-product costs. Figure 8 presents the percentage variation in the worst and best cases for the investigated onshore and offshore UCG-CCS/CCU end-uses, determined within the sensitivity analysis and compared to current market prices.

Table 22. Different UCG channel widths and resulting levelized methanol and ammonia costs.

\begin{tabular}{|c|c|c|c|c|c|c|c|c|}
\hline \multirow[t]{2}{*}{$\begin{array}{l}\text { Channel } \\
\text { Width (m) }\end{array}$} & \multicolumn{2}{|c|}{$\begin{array}{l}\text { Required } \\
\text { Channels (-) }\end{array}$} & \multicolumn{2}{|c|}{$\begin{array}{l}\text { Drilling } \\
\text { Length }(\mathbf{k m})\end{array}$} & \multicolumn{2}{|c|}{$\begin{array}{l}\text { Drilling } \\
\text { Costs (M€) }\end{array}$} & \multirow[t]{2}{*}{$\begin{array}{l}\text { MeOH Costs } \\
(€ / t \mathrm{MeOH})\end{array}$} & \multirow[t]{2}{*}{$\begin{array}{l}\mathrm{NH}_{3} \text { Costs } \\
\left(€ / \mathrm{t} \mathrm{NH}_{3}\right)\end{array}$} \\
\hline & $\mathrm{MeOH}$ & $\mathbf{N H}_{3}$ & $\mathrm{MeOH}$ & $\mathbf{N H}_{3}$ & $\mathrm{MeOH}$ & $\mathbf{N H}_{3}$ & & \\
\hline 50 & 53 & 31 & 173.7 & 101.6 & 245.8 & 143.8 & 348.5 & 505.3 \\
\hline 100 & 32 & 20 & 104.9 & 65.7 & 148.4 & 92.8 & 333.9 & 490.9 \\
\hline 150 & 25 & 12 & 82.0 & 39.3 & 116.0 & 55.6 & 326.0 & 485.0 \\
\hline 200 & 17 & 10 & 55.7 & 32.8 & 78.8 & 46.4 & 322.2 & 483.5 \\
\hline
\end{tabular}

In summary, sensitivity analysis results for the onshore scenarios showed that UCG synthesis gas-based electricity and methanol production can compete on the market even under the worst-case assumptions. With regard to ammonia production, only the onshore worst-case scenario was not economically competitive. Sensitivity analysis results on drilling costs and gasification channel widths for the offshore scenarios reveal that UCG-based methanol production was competitive, whereby ammonia production was not. 


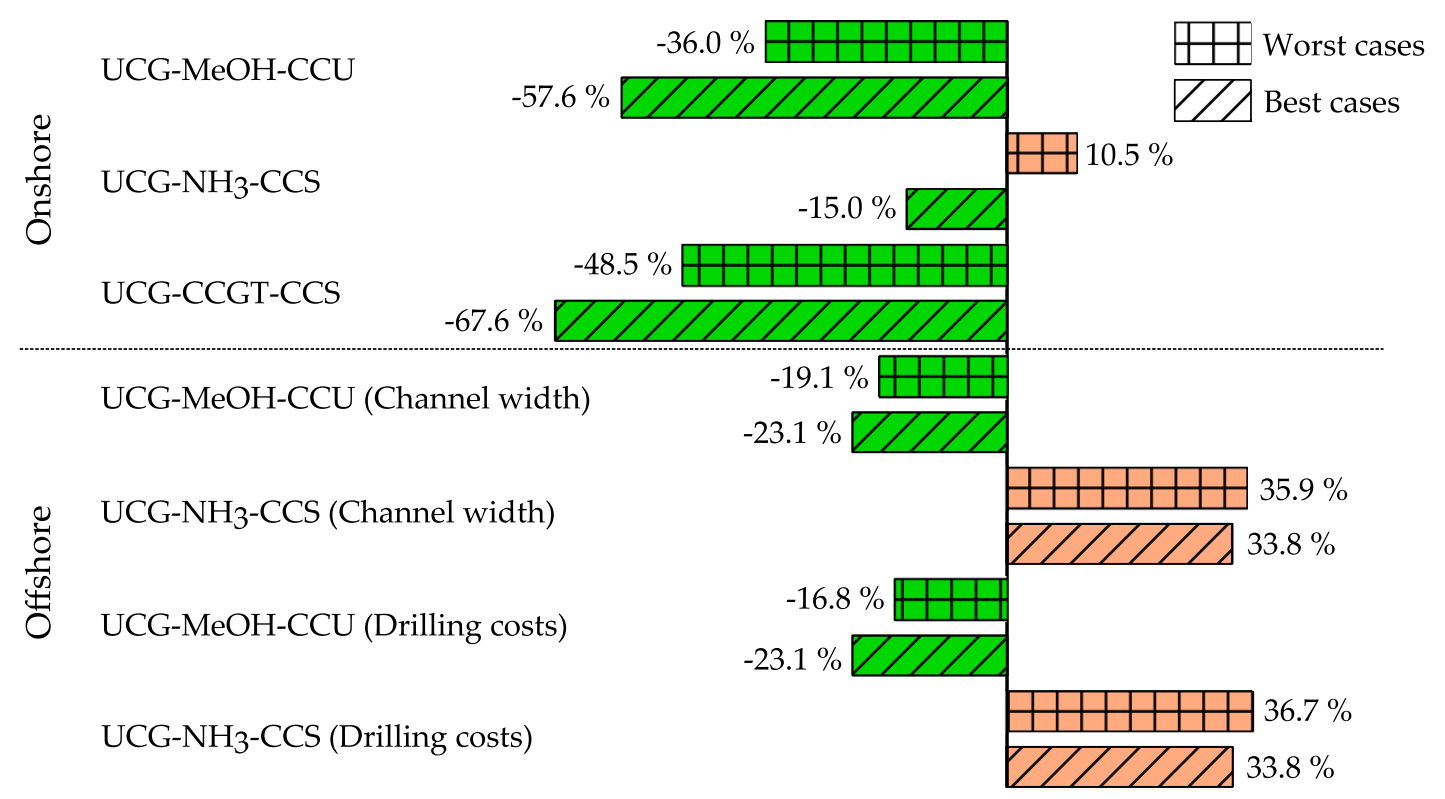

Figure 8. Percentage variation of the best- and worst-case costs in the underground coal gasification-based onshore (electricity, methanol, ammonia production) and offshore scenarios (methanol and ammonia production) to the current market prices.

\section{Discussion and Conclusions}

In the present study, we applied an enhanced techno-economic model based on Nakaten et al. [5] to determine levelized costs for integrated onshore UCG-CCS/CCU end-use options. Electricity generation (47€/MWh with CCS), as well as methanol $(206 € / \mathrm{t} \mathrm{MeOH})$ and ammonia $(298 € / \mathrm{t}$ ammonia) production were considered in the reference scenario. Modeling results showed that with the exception of the worst-case ammonia production scenario, the investigated onshore UCG synthesis gas end-use options can compete on the energy market, even with CCS costs considered. An offshore UCG-CCS/CCU model was applied to determine the levelized costs for methanol (322€/t MeOH) and ammonia production ( $484 € / \mathrm{t}$ ammonia). Modeling results exhibited that offshore methanol and ammonia production costs were up to 1.6 times higher than in the onshore scenarios. Hereby, only UCG-based methanol production was economically competitive.

OAT sensitivity analyses were applied to investigate the techno-economics in view of model input data variation and availability, model parametrization and boundary conditions. Hereby, we assessed four synthesis gas compositions, and consequently different synthesis gas CVs $\left(3.6-5.8 \mathrm{MJ} / \mathrm{sm}^{3}\right)$ within the scope of four onshore scenarios. This model input parameter was selected for further investigation within the sensitivity analysis, since even small changes in process conditions were likely to induce significant changes in the resulting synthesis gas composition and its suitability as a UCG end-product. For the proposed offshore UCG well layout, we investigated the impact of varying gasification channel widths and drilling costs in seven offshore scenarios. For that purpose, we chose offshore drilling costs and gasification channel widths as objective parameters in the OAT sensitivity analysis, especially due to the lack of data on offshore drilling costs and practical experience related to the assumed maximum achievable gasification channel width.

Supplying different coal types, synthesis gas compositions, calorific values, and gasification agent compositions, OAT sensitivity analysis results revealed five factors that mainly impacted the competitiveness of the investigated UCG-CCS/CCU process chains. These comprised the share of oxygen in the gasification agent, availability of required synthesis gas components $\left(\mathrm{H}_{2}, \mathrm{~N}_{2}\right)$, installed net capacity, the economy of scale effect, as well as the required power. Hereby, ASU costs had the strongest effect on total levelized costs, since scenarios with an $\mathrm{O}_{2}$ share above $30 \%$ were the most expensive ones, while the highest synthesis gas $\mathrm{CVs}$ were achieved and all synthesis gas components 
required for the end-uses provided. Other factors exhibited only minor impacts in the underlying study. The economy of scale takes effect only for products without a fixed output (e.g., synthesis gas production) in contrast to methanol and ammonia production, where the produced output was maintained constant for all scenarios for comparability. Hence, taking into account all considered synthesis gas compositions with a maximum deviation of $43 \%$ for $\mathrm{H}_{2}, 72 \%$ for $\mathrm{CO}_{2}$, and $43 \%$ for the $\mathrm{N}_{2}$ content, as well as $37 \%$ in view of the $\mathrm{CV}$, cost variations of $23 \%$ (ammonia production) up to $39 \%$ (electricity generation) were determined. Hereby, the most favorable synthesis gas composition for power generation ( $30 € / \mathrm{MWh}$ with CCS) and methanol production (178€/t methanol with CCU/CCS) was represented by Scenario III. Optimum ammonia production $(272 € / \mathrm{t}$ ammonia with CCS) was achieved within Scenario II. Requirements for production at low-costs were pure air gasification, high synthesis gas $\mathrm{CV}$, high installed net capacity, and the availability of the required synthesis gas components $\left(\mathrm{H}_{2}, \mathrm{~N}_{2}\right)$. The least favorable synthesis gas composition in view of power generation ( $47 € /$ MWh with CCS) was that in Scenario I and for methanol (268€/t methanol with CCU/CCS) and ammonia production ( $354 € / \mathrm{t}$ ammonia with CCS) that in Scenario IV.

Sensitivity analysis results on offshore drilling costs showed that due to the small share of drilling costs on the total costs, total levelized methanol and ammonia production costs were only marginally affected. Thus, increasing drilling costs by the 10- and 15-fold, compared to the reference scenario, caused a linear methanol and ammonia production cost increment by $8.3 € / \mathrm{t}$ methanol and by $7.8 € / \mathrm{t}$ ammonia. Different gasification channel widths impacted the extractable coal amount per channel and, hence, the required number of channels to maintain the daily coal demand. Varying the gasification channel width by $150 \mathrm{~m}$ resulted in a difference in drilling meters of up to $68 \%$. However, due to the low impact of drilling costs on total costs, levelized methanol and ammonia production costs differed by up to $7.5 \%$, only.

Based on the findings elaborated in the present study, we drew the following conclusions:

- Except from ammonia production under the assumed worst-case conditions, the costs of the investigated onshore UCG-CCS/CCU scenarios were economically competitive on the European market.

- Boundary conditions supporting cost-effective electricity generation as well as methanol and ammonia production were characterized by air-blown gasification, and thus by lower power requirements for air separation and compression in the first place. In order not to exceed the synthesis gas $\mathrm{CO}_{2}$ share, an oxygen-based gasification agent ratio of more than $30 \%$ by volume was not favorable; neither from an economic point of view, nor for $\mathrm{CO}_{2}$ emission mitigation. Besides, synthesis gas compositions that favored methanol and ammonia production exhibited adequate shares of $\mathrm{H}_{2}$ and $\mathrm{N}_{2}$.

- Offshore UCG-based methanol and ammonia production costs were about 1.6 times higher than the respective onshore costs, whereby only UCG-based methanol production was economically competitive on the EU market.

- Compared to the offshore platform with its technical equipment, drilling costs had a minor impact on total levelized costs. Thus, uncertainties in relation to parameters influenced by drilling costs were negligible. A parameter of high uncertainty was the maximum achievable channel width in P-CRIP UCG operations, which has to be further investigated in UCG field tests.

- The impact of boundary conditions and synthesis gas compositions that favored or hampered UCG-based end-product cost-effectiveness in the present study may change, if the methanol and ammonia outputs are not constant for all scenarios and economies of scale take effect. In the underlying study, economies of scale only occurred in the context of synthesis gas production, which was not fixed, but iteratively adjusted to the overall required gross generation.

Aiming at an improved comparability between the different UCG-CCS/CCU end-product costs in the scope of the present study, total levelized costs were determined separately from each other. However, future investigations will aim at the integration of different production chains to quantify cost savings resulting from the synergies of similar processes (e.g., $\mathrm{H}_{2} / \mathrm{CO}_{2}$ separation), 
shared infrastructure (e.g., compression, piping systems), as well as the utilization of excess heat in heat exchangers or additional electricity supply. Besides, future research activities will focus on the implementation of costs taking into account the potential environmental impacts of UCG-CCS/CCU.

Author Contributions: N.N. and T.K. conceived of and designed research; N.N. performed the research; N.N. and T.K. analyzed the data; N.N. and T.K. wrote the paper.

Funding: The authors gratefully acknowledge the funding received for the EU-FP7 TOPS project (Grant 608517) by the European Commission (EC).

Acknowledgments: We thank all TOPS project partners for many fruitful discussions. Special thanks go to our colleagues Krzysztof Kapusta, who contributed with knowledge on coal-related data for the study area, as well as Dorota Burchart-Korol (Główny Instytut Górnictwa, Katowice, Poland), who contributed Polish onshore drilling data. We further would like to thank Robert Schmidt, who was involved in the ammonia synthesis model development.

Conflicts of Interest: The authors declare no conflict of interest.

\section{Abbreviations}

The following abbreviations are used in this manuscript:

$\begin{array}{ll}\text { ASU } & \text { Air separation unit } \\ \text { CAPEX } & \text { Capital expenditure } \\ \text { CCGT } & \text { Combined cycle gas turbine } \\ \text { CCS } & \text { Carbon capture and storage } \\ \text { CCU } & \text { Carbon capture and utilization } \\ \text { COE } & \text { Costs of electricity } \\ \text { CRIP } & \text { Controlled retraction injection point } \\ \text { EOS } & \text { Equation of state } \\ \text { IECM } & \text { Integrated environmental control model } \\ \text { OAT } & \text { One-at-a-time } \\ \text { OFS } & \text { Offshore } \\ \text { ONS } & \text { Onshore } \\ \text { OPEX } & \text { Operational expenditure } \\ \text { P-CRIP } & \text { Parallel controlled retracting injection point } \\ \text { UCG } & \text { Underground coal gasification }\end{array}$

\section{References}

1. Hewing, G.; Hewel-Bundermann, H.; Krabiell, K.; Witte P. Post-1987 Research and Development Studies of Underground Coal Gasification; Research Association for Second-Generation Coal Extraction: Essen, Germany, 1988.

2. Klimenko, A. Early Ideas in Underground Coal Gasification and Their Evolution. Energies 2009, 2, 456-476. [CrossRef]

3. Prabu, V.; Jayanti, S. Simulation of cavity formation in underground coal gasification using bore hole combustion experiments. Energy 2011, 36, 5854-5864. [CrossRef]

4. Prabu, V.; Jayanti, S. Integration of underground coal gasification with a solid oxide fuel cell system for clean coal utilization. Hydrog. Energy 2012, 37, 1677-1688. [CrossRef]

5. Nakaten, N.C.; Schlüter, R.; Azzam, R.; Kempka, T. Development of a techno-economic model for dynamic calculation of $\mathrm{COE}$, energy demand and $\mathrm{CO}_{2}$ emissions of an integrated UCG-CCS process. Energy 2014, 66, 779-790. [CrossRef]

6. Otto, C.; Kempka, T. Prediction of Steam Jacket Dynamics and Water Balances in Underground Coal Gasification. Energies 2017, 10, 739. [CrossRef]

7. Kapusta, K.; Stańczyk, K. Pollution of water during underground coal gasification of hard coal and lignite. Fuel 2011, 90, 1927-1934. [CrossRef]

8. Stańczyk, K, Howaniec, N.; Smolinski, A.; Swiadrowski, J.; Kapusta, K.; Wiatowski, M.; Grabowski, J.; Rogut, J. Gasification of lignite and hard coal with air and oxygen enriched air in a pilot scale ex-situ reactor for underground gasification. Fuel 2011, 90, 1953-1962. [CrossRef] 
9. Kapusta, K.; Stańczyk, K.; Wiatowski, M.; Chećko, J. Environmental aspects of a field-scale underground coal gasification trial in a shallow coal seam at the Experimental Mine Barbara in Poland. Fuel 2013, 113, 196-208. 2013.05.015. [CrossRef]

10. Stańczyk, K. Experience of Central Mining Institute in Underground Coal Gasification-Research and Pilot Test in "KWK Wieczorek" Mine. 2015. Available online: http:/ /www.fossilfuel.co.za (accessed on 26 September 2017).

11. Kinaev, N.; Belov, A.; Bongers, G.; Grebenyuk, I.; Vinichenko, I. Integrated assessment of feasibility of coal-to-chemical projects. In Proceedings of the 8th International Freiberg Conference on IGCC \& XtL Technologies: Innovative Coal Value Chains, Cologne, Germany, 12-26 June 2016.

12. NCBiR Project. Development of Coal Gasification Technology for Highly Efficient Production of Fuels and Electricity; Project Report; 2015; unpublished.

13. EURACOAL. Mineable Coal and Lignite Reserves Poland. 2016. Available online: http://euracoal2.org (accessed on 9 December 2016).

14. Czaplicka-Kolarz, K.; Krawczyk, P.; Ludwik-Pardala, M.; Burchart-Korol, D. Cost-effectiveness of underground coal gasification by the shaft method. Przem. Chem. 2015, 94, 1708-1713. [CrossRef]

15. Burchart-Korol, D.; Korol, J.; Czaplicka-Kolarz, K. Life cycle assessment of heat production from underground coal gasification. Int. J. Life Cycle Assess. 2016, 21, 1391-1403. [CrossRef]

16. EC. Energy Roadmap 2050; European Commission: Brussels, Belgium, 2011. Available online: http:/ / eur-lex. europa.eu (accessed on 15 February 2017).

17. Pérez-Fortes, M.; Schöneberger, J.C.; Boulamanti, A.; Tzimas, E. Methanol synthesis using captured $\mathrm{CO}_{2}$ as raw material: Techno-economic and environmental assessment. Appl. Energy 2016, 161, 718-732. [CrossRef]

18. EC. Large Volume Inorganic Chemicals-Solids and Others; European Commission: Brussels, Belgium, August 2007. Available online: https:/ / www.mpo.cz (accessed on 22 September 2017)

19. Otto, C.; Kempka, T.; Kapusta, K.; Stańczyk, K. Fault Reactivation Can Generate Hydraulic Short Circuits in Underground Coal Gasification-New Insights from Regional-Scale Thermo-Mechanical 3D Modeling. Minerals 2016, 6, 101. [CrossRef]

20. Otto, C.; Kempka, T. Thermo-mechanical Simulations Confirm: Temperature-dependent Mudrock Properties are Nice to have in Far-field Environmental Assessments of Underground Coal Gasification. Energy Procedia 2015, 76, 582-591. [CrossRef]

21. Otto, C.; Kempka, T. Thermo-Mechanical Simulations of Rock Behavior in Underground Coal Gasification Show Negligible Impact of Temperature-Dependent Parameters on Permeability Changes. Energies 2015, 8, 5800-5827. [CrossRef]

22. DWSIM. Open-Source CAPE-OPEN Compliant Chemical Process Simulator. Available online: http:// dwsim.inforside.com.br (accessed on 12 December 2016).

23. ChemSep. Modeling Separation Processes, Databases. Available online: http://www.chemsep.org (accessed on 12 December 2016).

24. Godbolt, B. Scientific Drilling UCG Training School, Directional Drilling in Coal. 2011. Available online: http:/ / repository.icse.utah.edu (accessed on 12 December 2016).

25. Kempka, T.; Fernandez-Steeger, T.; Li, D.; Schulten, M.; Schlter, R.; Krooss, B. Carbon dioxide sorption capacities of coal gasification residues. Environ. Sci. Technol. 2011, 45, 1719-1723. [CrossRef] [PubMed]

26. Najafi, M.; Jalali, S.M.E.; KhaloKakaie, R. Thermal-Mechanical Numerical Analysis of Stress Distribution in the vicinity of Underground Coal Gasification (UCG) Panels. Int. J. Coal Geol. 2014, 134-135, 1-16. [CrossRef]

27. Świadrowski, J.; Mocek, P.; Jedrysik, E.; Stańczyk, K.; Krzemień, J.; Krawczyk, P.; Chećko, J. Demonstration facility for underground coal gasification. CHEMIK 2015, 69, 815-826.

28. KOPEX. The Draft Technical Installations PZW on KWK Wieczorek; Project Report; KOPEX Construction Company Szybów, SA: Ibadan, Nigeria, 2012.

29. Acheick, A.M.; Batto, S.F.; Changmoon, Y.; Chien, S.C.; Choe, J.I.; Cole, K.R.; Engel, K.; Gardner, W.; Gilbert, S.N.; Hui, Y.; et al. Viability of Underground Coal Gasification with Carbon Capture and Storage in Indiana; Indiana University-Bloomington School of Public and Environmental Affairs: Bloomington, IN, USA, 2011. Available online: http: / / www.indiana.edu (accessed on 20 January 2017).

30. Integrated Environmental Control Model (IECM). A Tool for Calculating the Performance, Emissions, and Cost of a Fossil-Fueled Power Plant (Version 8.0.1 Beta). Available online: http:/ / www.iecm-online.com (accessed on 12 December 2016). 
31. Cardenas Barranon, D.C. Methanol and Hydrogen Production. Master's Thesis, 2006. Available online: http:/ / ltu.diva-portal.org (accessed on 18 September 2017).

32. Hillebrand, B. Stromerzeugungskosten Neu zu Errichtender Konventioneller Kraftwerke; RWI-Papiere Nr. 47; Rheinisch-Westfälisches Institut für Wirtschaftsforschung, Essen, Germany, 1997.

33. Schneider, L. Stromgestehungskosten von Großkraftwerken; Öko-Institut e.V.: Berlin, Germany, 1998. Available online: http:/ / www.oeko.de (accessed on 12 December 2016).

34. Chen, K.D.; Yu, L. Experimental study on long-tunnel large-section two-stage underground coal gasification. In Mining Science and Technology; T.S. Golosinski, Guo Yuguan; Balkema, Rotterdam 1996; pp. 313-316.

35. Creedy, D.P.; Garner, K. Clean Energy from Underground Coal Gasification in China; COAL R250 DTI/Pub URN 03/1611; Department of Trade and Industry: London, UK, 2004.

36. Couch, G.R. Underground Coal Gasification; CCC/151; IEA Clean Coal Centre: London, UK, 2009.

37. Nakaten, N.; Kempka, T. Radial-symmetric well design to optimize coal yield and maintain required safety pillar width in oshore underground coal gasification. Energy Procedia 2017, 125, 27-33. [CrossRef]

38. Boeing, N. Bohrende Fragen. Tech. Review. Magazin für Innovation. 2010. Available online: https: / / www.heise.de (accessed on 12 December 2016).

39. Gräbner, M.; Morstein, O.; Rappold, D.; Gunster, W.; Beysel, G.; Meyer, B. Constructability study on a German reference IGCC power plant with and without $\mathrm{CO}_{2}$ capture for hard coal and lignite. Energy Convers. Manag. 2010, 51, 2179-2187. [CrossRef]

40. Zero emissions platform (ZEP). The Costs of $\mathrm{CO}_{2}$ Capture. 2011. Available online: http://www. zeroemissionsplatform.eu (accessed on 12 December 2016).

41. Mohammed, I.Y.; Samah, M.; Mohamed, A.; Sabina, G. Comparison of SelexolTM and Rectisol Technologies in an Integrated Gasification Combined Cycle (IGCC) Plant for Clean Energy Production. IJER 2014, 3, 742-744. [CrossRef]

42. Hammond, G.P.; Ondo Akwe, S.S.; Williams, S. Techno-economic appraisal of fossil-fuelled power generation systems with carbon dioxide capture and storage. Energy 2011, 36, 975-984. [CrossRef]

43. Li, H.; Ditaranto, M.; Berstad, D. Technologies for increasing $\mathrm{CO}_{2}$ concentration in exhaust gas from natural gas-fired power production with post-combustion, amine-based $\mathrm{CO}_{2}$ capture. Energy 2011, 36, 1124-1133. [CrossRef]

44. Ausfelder, F.; Bazzanella, A. Diskussionspapier Verwertung und Speicherung von $\mathrm{CO}_{2}$; DECHEMA e.V.: Frankfurt am Main, Germany, 2008. Available online: https: / / dechema.de (accessed on 12 December 2016).

45. Katofsky, R.E.The Production of Fluid Fuels From Biomass; Princeton University: Princeton, NJ, USA, 1993. Available online: http:/ / acee.princeton.edu (accessed on 18 September 2017).

46. Komiyama, H.; Mitsumori, T.; Yamaji, K.; Yamada, K. Assessment of energy systems by using biomass plantation. Fuel 2001, 80, 707-715. [CrossRef]

47. Burton, E.; Friedmann, J.; Upadhye, R. Best Practices in Underground Coal Gasification; Contract No. W-7405-Eng-48; Lawrence Livermore National Laboratory: Livermore, CA, USA, 2006. Available online: http:/ / www.purdue.edu (accessed on 6 January 2014).

48. SiteChar Project. Characterisation of European $\mathrm{CO}_{2}$ Storage; Project Report, Deliverable D2.2 Economic Assessment. Unpublished work, 2013.

49. Kunkes, E.; Behrens, M. Methanol Chemistry. In Chemical Energy Storage; Walter de Gruyter: Berlin, Germany, 2013. Available online: http:/ / pubman.mpdl.mpg.de (accessed on 20 September 2017).

50. Moffat, A.S. Methanol-powered. Science 1991, 251, 515-515.

51. Olah, G.A.; Goeppert, A.; Prakash, G.K.S. Beyond Oil and Gas: The Methanol Economy; Wiley-VCH. XIV: Weinheim an der Bergstrasse, Germany, 2006.

52. Van-Dal, E.; Bouallou, C. $\mathrm{CO}_{2}$ abatement through a methanol production process. Chem. Eng. Trans. 2012, 29, 463-468. [CrossRef]

53. Villesca, J.; Bala, V.; Garcia, A. Reactor Project: Ammonia Synthesis. Available online: http://www.owlnet. rice.edu/ ceng403/nh3syn97.html (accessed on 20 August 2019)

54. Penkuhn, M.; Tsatsaronis, G. Comparison of different ammonia synthesis loop configurations with the aid of advanced exergy analysis. In Proceedings of the ECOS, 29th International Conference on Efficiency, Cost, Optimization, Simulation and Environmental Impact of Energy Systems, Portoroz, Slovenia, 19-23 June 2016. Available online: http:/ / www.owlnet.rice.edu (accessed on 20 September 2017). 
55. Nakaten, N.C.; Islam, R.; Kempka, T. Underground Coal Gasification with Extended $\mathrm{CO}_{2}$ Utilization-An Economic and Carbon Neutral Approach to Tackle Energy and Fertilizer Supply Shortages in Bangladesh. Energy Procedia 2014, 63, 8036-8043. [CrossRef]

56. Ernst\&Young. Wplyw Energetyki Wiatrowej Na Wzrost Gospodarczy w Polsce. 2012. Available online: http:/ / domrel.pl (accessed on 12 December 2016).

57. Zaporowski, B. Koszty Wytwarzania Energii Elektrycznej Dla Perspektywicznych Technologii WytwóRczych Polskiej Elektroenergetyki. Polityka Energetyczna 2012, 15, 43-55. Available online: https:/ / www.min-pan. krakow.pl (accessed on 12 December 2016).

58. Central Statistical Office of Poland (CSOP). The Economy of Fuel and Energy in 2013 and 2014; Central Statistical Office of Poland: Warszawa, Poland, 2015. Available online: http://stat.gov.pl/ (accessed on 12 December 2016).

59. ERO. Information of the President of the Energy Regulatory Office No. 3/2015. 2015. Available online: https:/ / www.kpmg.com (accessed on 29 February 2014).

60. ERO. Information of President of Energy Regulatory Office No. 46/2015. 2015. Available online: https: / /www.ure.gov.pl (accessed on 4 November 2016).

61. McCollum, D. and Ogden, J. Techno-Economic Models for Carbon Dioxide Compression, Transport, and Storage. Correlations for Estimating Carbon Dioxide Density and Viscosity; Institute of Transportation Studies (ITS), University of California: Berkeley, CA, USA, 2006. Available online: http://www.its.ucdavis.edu (accessed on 30 January 2019).

62. Methanex. The Power of Agility. 2018. Available online: https://www.methanex.com (accessed on 28 September 2018)

63. Bartels, J.R. A feasibility study of implementing an Ammonia Economy. Master's Thesis, Iowa State University, Ames, Iowa, USA, 2008. Available online: http://lib.dr.iastate.edu (accessed on 20 September 2017).

64. AMIS. Fertilizer Outlook. Market Monitor. 2018. Available online: http://www.fao.org (accessed on 1 October 2018).

65. Klebingat, S.; Kempka, T.; Schulten, M.; Azzam, R.; Fernández-Steeger, T.M. Innovative thermodynamic underground coal gasification model for coupled synthesis gas quality and tar production analyses. Fuel 2016, 183, 680-686. [CrossRef]

66. Klebingat, S.; Kempka, T.; Schulten, M.; Azzam, R.; Fernández-Steeger, T. M. Optimization of synthesis gas heating values and tar by-product yield in underground coal gasification. Fuel 2018, 229, 248-261. [CrossRef]

67. Mocek, P.; Pieszczek, M.; Swiadrowski, J.; Kapusta, K.; Wiatowski, M.; Stańczyk, K. Pilot-scale underground coal gasification (UCG) experiment in an operating Mine “Wieczorek" in Poland. Energy 2016, 111, 313-321. [CrossRef]

(C) 2019 by the authors. Licensee MDPI, Basel, Switzerland. This article is an open access article distributed under the terms and conditions of the Creative Commons Attribution (CC BY) license (http://creativecommons.org/licenses/by/4.0/). 